\title{
Synthesis of Phantasmidine
}

\author{
Quan Zhou and Barry B. Snider*
}

Dept. of Chemistry MS 015, Brandeis University, Waltham, Massachusetts 02454-9110

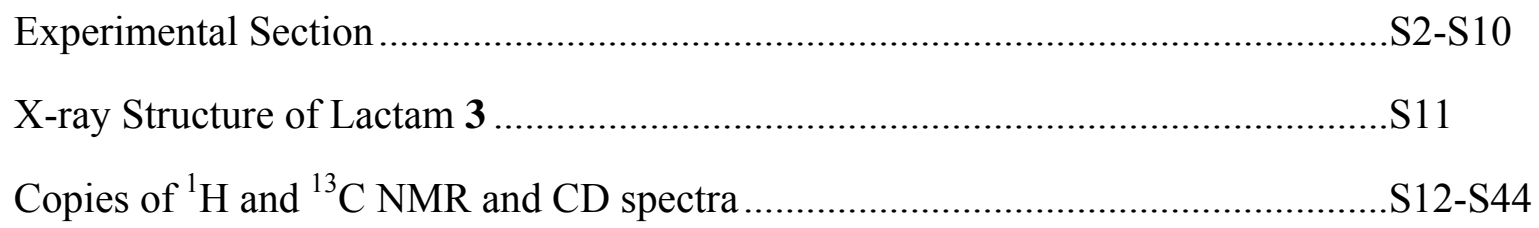


General Experimental Methods. Reactions were conducted in flame- or oven-dried glassware under a nitrogen atmosphere and were stirred magnetically. The phrase "concentrated" refers to removal of solvents by means of a rotary evaporator attached to a diaphragm pump (1560 Torr) followed by removal of residual solvents at $<1$ Torr with a vacuum pump. Flash chromatography was performed on silica gel 60 (230-400 mesh). Analytical thin layer chromatography (TLC) was performed using silica gel 60 F-254 pre-coated glass plates $(0.25 \mathrm{~mm})$. TLC Plates were analyzed by short wave UV illumination, or by dipping in vanillin stain ( $27 \mathrm{~g}$ of vanillin in $380 \mathrm{~mL}$ of EtOH, $50 \mathrm{~mL}$ of water and $20 \mathrm{~mL}$ of concentrated sulfuric acid) and heating on a hot plate or by spray with permanganate spray ( $5 \mathrm{~g}$ of $\mathrm{KMnO}_{4}$ in $495 \mathrm{~mL}$ of water). $\mathrm{THF}$ and ether were dried and purified by distillation from sodium/benzophenone. DIPEA, $\mathrm{Et}_{3} \mathrm{~N}$, $\mathrm{MeOH}$, and benzene were distilled from $\mathrm{CaH}_{2} \cdot{ }^{1} \mathrm{H}$ and ${ }^{13} \mathrm{C}$ NMR spectra were obtained on a 400 $\mathrm{MHz}$ spectrometer in $\mathrm{CDCl}_{3}$ with tetramethylsilane as internal standard unless otherwise indicated. Chemical shifts are reported in $\delta$ (ppm downfield from tetramethylsilane). Coupling constants are reported in $\mathrm{Hz}$ with multiplicities denoted as s (singlet), d (doublet), $\mathrm{t}$ (triplet), q (quartet), $\mathrm{p}$ (pentet), m (multiplet) and br (broad). COSY spectra were recorded for all compounds and used to assign ${ }^{1} \mathrm{H}$ NMR spectra. IR spectra were acquired on an FT-IR spectrometer and are reported in wave numbers $\left(\mathrm{cm}^{-1}\right)$. High resolution mass spectra were obtained using the following ionization techniques: chemical ionization $(\mathrm{CI})$, electron impact (EI), electrospray ionization analyzed by quadrupole time of flight (QTOF).

2,6-Dichloro-3-pyridinemethanol (9a). A solution of 2,6-dichloropyridine-3carboxaldehyde (8a) $(950 \mathrm{mg}, 5.40 \mathrm{mmol})$ in $\mathrm{MeOH}(10 \mathrm{~mL})$ was treated with $\mathrm{NaBH}_{4}(205 \mathrm{mg}$, $5.40 \mathrm{mmol}$ ) in one portion at $0^{\circ} \mathrm{C}$. The reaction was stirred at $0^{\circ} \mathrm{C}$ for $30 \mathrm{~min}$. Aqueous hydrochloric acid $(10 \%)$ was added dropwise to the reaction until $\mathrm{pH} 1$ was reached and $\mathrm{MeOH}$ was removed under vacuum. The residue was extracted with $\mathrm{CH}_{2} \mathrm{Cl}_{2}(50 \mathrm{~mL} \times 3)$. The combined $\mathrm{CH}_{2} \mathrm{Cl}_{2}$ layers were washed with $\mathrm{H}_{2} \mathrm{O}(50 \mathrm{~mL})$ and brine $(50 \mathrm{~mL})$, dried $\left(\mathrm{Na}_{2} \mathrm{SO}_{4}\right)$, and concentrated to give $952 \mathrm{mg}(99 \%)$ of 9 a as a white solid, which was used directly without further purification. A small portion of crude 9a was recrystallized to give an analytical sample: 
mp 73-74 ${ }^{\circ} \mathrm{C}\left(\right.$ lit. $\left.^{5 \mathrm{a}} 62-64{ }^{\circ} \mathrm{C}\right) ;{ }^{1} \mathrm{H}$ NMR $7.88(\mathrm{~d}, 1, J=8.0), 7.33$ (d, 1, J=8.0), 4.78 (br s, 2), $2.21\left(\right.$ br s, $\left.1, \mathrm{w}_{1 / 2}=16, \mathrm{OH}\right) ;{ }^{13} \mathrm{C}$ NMR 148.8, 147.8, 139.1, 133.8, 123.2, 60.9; IR 3369. The data are identical to those previously reported. ${ }^{8 \mathrm{a}}$

2,6-Dichloro-3-pyridineacetonitrile (11a). A solution of 9a ( $848 \mathrm{mg}, 4.76 \mathrm{mmol})$ in $5 \mathrm{~mL}$ of $\mathrm{CH}_{2} \mathrm{Cl}_{2}$ was treated with $5 \mathrm{~mL}$ of $\mathrm{SOCl}_{2}$ and 3 drops of DMF at $0{ }^{\circ} \mathrm{C}$. The resulting solution was stirred at $0{ }^{\circ} \mathrm{C}$ for $1 \mathrm{~h}$ and then warmed to $25^{\circ} \mathrm{C}$ and stirred for another $5 \mathrm{~h}$. The reaction was concentrated. The residue was dissolved in $50 \mathrm{~mL}$ of $\mathrm{CH}_{2} \mathrm{Cl}_{2}$ and the solution was washed with saturated $\mathrm{NaHCO}_{3}$ and brine, dried $\left(\mathrm{Na}_{2} \mathrm{SO}_{4}\right)$, and concentrated to give $1.02 \mathrm{~g}$ of crude 2,6-dichloro-3-chloromethylpyridine (10a), which was used without further purification. A small portion of crude 10a was recrystallized to give an analytical sample: mp $83-84{ }^{\circ} \mathrm{C} ;{ }^{1} \mathrm{H}$ NMR $7.82(\mathrm{~d}, 1, J=8.0), 7.33(\mathrm{~d}, 1, J=8.0), 4.66(\mathrm{~s}, 2) ;{ }^{13} \mathrm{C}$ NMR 150.1, 149.5, 141.2, 130.6, 123.5, 41.8; IR 1580, 1552, 1426, 1353. The data are identical to those previously reported. ${ }^{9 b}$ A solution of crude 10a dissolved in $20 \mathrm{~mL}$ 9:1 EtOH/ $\mathrm{H}_{2} \mathrm{O}$ was treated with $\mathrm{NaCN}$ (466 mg, $9.52 \mathrm{mmol}$ ). The resulting solution was heated at $80{ }^{\circ} \mathrm{C}$ for $4 \mathrm{~h}$. The reaction was cooled and diluted with $\mathrm{H}_{2} \mathrm{O}(50 \mathrm{~mL})$, and extracted with $\mathrm{CH}_{2} \mathrm{Cl}_{2}(3 \times 50 \mathrm{~mL})$. The combined organic layers were washed with $\mathrm{H}_{2} \mathrm{O}$ and brine and dried $\left(\mathrm{Na}_{2} \mathrm{SO}_{4}\right)$. Concentration gave $952 \mathrm{mg}$ of crude 11a. Flash chromatography (5:1 hexanes/EtOAc) gave $572 \mathrm{mg}$ (64\%) of pure 11a: mp 90-91 ${ }^{\circ} \mathrm{C}$ (lit. ${ }^{9 b} 80-82{ }^{\circ} \mathrm{C}$, lit. $^{9 \mathrm{a}} 89-91{ }^{\circ} \mathrm{C}$ ); ${ }^{1} \mathrm{H}$ NMR 7.86 (d, 1, J=8.0), 7.38 (d, 1, J=8.0), 3.85 (s, 2); ${ }^{13} \mathrm{C}$ NMR 150.4, 149.3, 140.2, 124.0, 123.7, 115.4, 21.4; IR 2265. The ${ }^{1} \mathrm{H}$ NMR data are identical to those previously reported. ${ }^{9 \mathrm{~d}}$

2,6-Dichloro-3-pyridineacetamide (6a). A mixture of 11a (410 mg, $2.19 \mathrm{mmol})$ and alumina (447 mg, $4.38 \mathrm{mmol})$ in $\mathrm{MsOH}(5 \mathrm{~mL})$ was heated at $120^{\circ} \mathrm{C}$ for $15 \mathrm{~min}$. The reaction was cooled and $\mathrm{H}_{2} \mathrm{O}(30 \mathrm{~mL})$ was added. The mixture was extracted with $\mathrm{CH}_{2} \mathrm{Cl}_{2}(30 \mathrm{~mL} \times 5)$. The combined $\mathrm{CH}_{2} \mathrm{Cl}_{2}$ layers were washed with brine $(30 \mathrm{~mL})$, dried $\left(\mathrm{MgSO}_{4}\right)$, and concentrated to give $370 \mathrm{mg}$ of $\mathbf{6 a}$ as a white solid. Crude $\mathbf{6 a}$ was washed with cold ether to give $315 \mathrm{mg}(70 \%)$ of pure 6a that was used directly for the next step: mp $175-176{ }^{\circ} \mathrm{C} ;{ }^{1} \mathrm{H} \mathrm{NMR}\left(\mathrm{CD}_{3} \mathrm{OD}\right) 7.79$ (d, 1 , 
$J=8.0), 7.40$ (d, $1, J=8.0), 3.71(\mathrm{~s}, 2) ;{ }^{13} \mathrm{C} \mathrm{NMR}\left(\mathrm{CD}_{3} \mathrm{OD}\right)$ 174.0, 151.7, 149.8, 144.,8, 131.2, 124.6, 39.6; IR 3408, 3205, 1667.

\section{2,6-Dichloro- $N$-(2-oxocyclobutyl)-3-pyridineacetamide (5a). Primary amide 6a}

(250 mg, $1.22 \mathrm{mmol}$ ) and 1,2-bis(trimethylsilyloxy)cyclobutene (7, $350 \mathrm{mg}, 1.52 \mathrm{mmol}$ ) in $5 \mathrm{~mL}$ of saturated $\mathrm{HCl}$ in anhydrous ether was sealed in a resealable tube. The reaction was heated at $80{ }^{\circ} \mathrm{C}$ for $2 \mathrm{~h}$ and cooled to $25^{\circ} \mathrm{C}$. The solvent was removed and the residue was dissolved in $30 \mathrm{~mL}$ of $\mathrm{CH}_{2} \mathrm{Cl}_{2}$. The solution was washed with saturated $\mathrm{NaHCO}_{3}$ to remove the side product 2,6-dichloro-3-pyridineacetic acid, brine, and dried $\left(\mathrm{Na}_{2} \mathrm{SO}_{4}\right)$. Concentration gave $309 \mathrm{mg}$ of light-yellow gummy material. Flash chromatography (25:1 $\left.\mathrm{CH}_{2} \mathrm{Cl}_{2} / \mathrm{MeOH}\right)$ gave $259 \mathrm{mg}(78 \%)$ of pure 5a as a white solid: $R_{f}=0.2\left(20: 1 \mathrm{CH}_{2} \mathrm{Cl}_{2} / \mathrm{MeOH}\right) ;{ }^{1} \mathrm{H} \mathrm{NMR} 7.70$ (d, $\left.1, J=8.0\right), 7.29$ (d, 1, $J=8.0$ ), 6.45 (br d, 1, $J=8.4, \mathrm{NH}$ ), 4.91 (ddd, $1, J=10.0,8.4,8.0$ ), 3.65 (s, 2), 2.96 (apparent dd, 2, $J=8.4,8.4, \mathrm{CH}_{2}$ group adjacent to ketone), 2.44 (dddd, $1, J=12.0,10.0,8.4,8.4$ ), 2.09 (dddd, 1, $J=12.0$, 8.4, 8.4, 8.4); ${ }^{13} \mathrm{C}$ NMR 205.0, 168.0, 150.1, 149.2, 142.4, 128.2, 123.4, 64.2, 42.1, 39.0, 19.3; IR 3299, 1786, 1654; HRMS (ESI+) calcd for $\mathrm{C}_{11} \mathrm{H}_{11} \mathrm{~N}_{2} \mathrm{O}_{2} \mathrm{Cl}_{2}\left(\mathrm{MH}^{+}\right)$273.0198, found 273.0198. Similar procedures have been reported for other primary amides. ${ }^{5 \mathrm{c}}$

\section{2-(t-Butoxycarbonyl)-4-(2,6-dichloro-3-pyridinyl)-2-azabicyclo[3.2.0]hept-4-en-3-}

one (14). A solution of secondary amide 5 a (14 mg, $51 \mu \mathrm{mol})$ in $3 \mathrm{~mL}$ of anhydrous $\mathrm{CH}_{2} \mathrm{Cl}_{2}$ was treated with $\mathrm{NEt}_{3}(35 \mu \mathrm{L}, 0.25 \mathrm{mmol})$ and DMAP $(2 \mathrm{mg})$ at $0{ }^{\circ} \mathrm{C}$. (Boc) $)_{2} \mathrm{O}(46 \mu \mathrm{L}, 0.2 \mathrm{mmol})$ was then added. The reaction was stirred at $0{ }^{\circ} \mathrm{C}$ for $15 \mathrm{~min}$ and $25{ }^{\circ} \mathrm{C}$ for another $45 \mathrm{~min} . \mathrm{H}_{2} \mathrm{O}$ was added and the resulting mixture was extracted with $\mathrm{CH}_{2} \mathrm{Cl}_{2}(10 \mathrm{~mL} \times 3)$. The combined $\mathrm{CH}_{2} \mathrm{Cl}_{2}$ layer was washed with $\mathrm{H}_{2} \mathrm{O}$ and brine and dried $\left(\mathrm{Na}_{2} \mathrm{SO}_{4}\right)$. Concentration gave $37 \mathrm{mg}$ of crude 14 contaminated with (Boc) $)_{2} \mathrm{O}$. Flash chromatography (5:1 hexanes/EtOAc) gave $11 \mathrm{mg}$ (61\%) of pure 14: ${ }^{1} \mathrm{H}$ NMR 8.29 (d, 1, $J=8.4$ ), 7.34 (d, 1, $J=8.4$ ), 5.03 (ddd, 1, $J=8.4,6.4,2$ ), 3.33 (ddd, 1, $J=14,9.2,9.2$ ), 2.95 (dddd, 1, $J=14,7.2$, 3, 2), 2.72 (dddd, 1, $J=9.6,9.2,8.4,3$ ), 1.57 (s, 9), 1.52 (dddd, $1, J=9.6,9.2,7.2,6.4) ;{ }^{13} \mathrm{C}$ NMR 169.6, 161.8, 149.32, 149.27, 148.6, 140.7, 124.9, 123.0, 119.3, 83.4, 63.1, 34.9, 28.1, 25.3. 
6-Chloro-2-fluoropyridine-3-carboxaldehyde (8b). A solution of diisopropylamine (5.80 mL, $41.5 \mathrm{mmol})$ in anhydrous THF (100 mL) was treated with $n$-BuLi (2.1 M in hexanes, $18.0 \mathrm{~mL}, 37.8 \mathrm{mmol})$ at $-78^{\circ} \mathrm{C}$. The cold bath was removed and the resulting solution was stirred at $0{ }^{\circ} \mathrm{C}$ for $30 \mathrm{~min}$. The light yellow solution was re-cooled to $-78{ }^{\circ} \mathrm{C}$ and 2-chloro-6fluoropyridine (15, $3.80 \mathrm{~g}, 29.0 \mathrm{mmol})$ in anhydrous THF (20 mL) was added dropwise. The reaction mixture was stirred at $-78{ }^{\circ} \mathrm{C}$ for $1 \mathrm{~h}$. Dimethylformamide $(4.49 \mathrm{~mL}, 58.0 \mathrm{mmol})$ was added dropwise and the mixture was stirred an additional $1 \mathrm{~h}$ and saturated $\mathrm{HCl}$ in ether was added at $-78{ }^{\circ} \mathrm{C}$ slowly to the mixture until $\mathrm{pH} 1$ was reached. The reaction was warmed to $25^{\circ} \mathrm{C}$ and $\mathrm{H}_{2} \mathrm{O}(50 \mathrm{~mL})$ was added. The layers were separated. The aqueous layer was extracted with EtOAc $(50 \mathrm{~mL} \times 2)$. The combined organic layers were washed with $\mathrm{H}_{2} \mathrm{O}(50 \mathrm{~mL})$ and brine (50 mL), dried $\left(\mathrm{MgSO}_{4}\right)$, and concentrated to give crystalline crude $\mathbf{8 b}$. The crude needles were recrystallized from hexanes to give $4.14 \mathrm{~g}(90 \%)$ of $\mathbf{8 b}: R_{f}=0.27$ (10:1 hexanes/EtOAc); mp 49-50 ${ }^{\circ} \mathrm{C} ;{ }^{1} \mathrm{H}$ NMR 10.27 (s, 1), 8.27 (dd, $\left.1, J=8.8,8.0\right), 7.41$ (d, $\left.J=8.0\right) ;{ }^{13} \mathrm{C}$ NMR 185.0, 162.6 (d, $J=254), 154.8$ (d, $J=15), 141.3$ (d, $J=2.3), 123.0$ (d, $J=5.3), 116.9$ (d, $J=21)$; IR 1697, 1595, 1562. The ${ }^{1} \mathrm{H}$ NMR spectrum is identical to that previously reported. ${ }^{12 a}$

6-Chloro-2-fluoro-3-pyridinemethanol (9b). A solution of $\mathbf{8 b}$ (2.00 g, $12.6 \mathrm{mmol})$ in $\mathrm{MeOH}(20 \mathrm{~mL})$ was treated with $\mathrm{NaBH}_{4}(479 \mathrm{mg}, 12.6 \mathrm{mmol})$ in portions over $5 \mathrm{~min}$ at $-10{ }^{\circ} \mathrm{C}$. The reaction was stirred at $-10^{\circ} \mathrm{C}$ for $30 \mathrm{~min}$. Aqueous hydrochloric acid (10\%) was added dropwise to the reaction until $\mathrm{pH} 1$ was reached and $\mathrm{MeOH}$ was removed under vacuum. The residue was extracted with $\mathrm{CH}_{2} \mathrm{Cl}_{2}(50 \mathrm{~mL} \times 3)$. The combined $\mathrm{CH}_{2} \mathrm{Cl}_{2}$ layers were washed with $\mathrm{H}_{2} \mathrm{O}(50 \mathrm{~mL})$ and brine $(50 \mathrm{~mL})$, dried $\left(\mathrm{Na}_{2} \mathrm{SO}_{4}\right)$, and concentrated to give $1.99 \mathrm{~g}$ of $\mathbf{9 b}$ as a white solid. Recrystallization from hexanes/EtOAc gave 1.84 g (91\%) of pure $9 \mathbf{b}: R_{f}=0.24$ (3:1 hexanes/EtOAc); mp 60-61 ${ }^{\circ} \mathrm{C} ;{ }^{1} \mathrm{H}$ NMR 7.91 (dd, 1, $\left.J=8.8,8.0\right), 7.26$ (d, 1, $J=8.0$ ), 4.75 (d, 2, $J=4.8), 2.80$ (t, $1, J=4.8, \mathrm{OH}) ;{ }^{13} \mathrm{C}$ NMR 159.1 (d, $\left.J=244\right), 147.1$ (d, $\left.J=14\right), 141.6(\mathrm{~d}, J=6)$, 121.8 (d, $J=5.3), 121.4$ (d, $J=27), 57.7$; IR 3230; HRMS (EI) calcd for $\mathrm{C}_{6} \mathrm{H}_{5} \mathrm{NClFO}\left(\mathrm{M}^{+}\right.$) 161.0044, found 161.0052 . 
6-Chloro-2-fluoro-3-pyridineacetonitrile (11b). A solution of 9 b (1.66 g, $10.3 \mathrm{mmol})$ in $10 \mathrm{~mL}$ of $\mathrm{CH}_{2} \mathrm{Cl}_{2}$ was treated with $10 \mathrm{~mL}$ of $\mathrm{SOCl}_{2}$ and 5 drops of DMF at $0{ }^{\circ} \mathrm{C}$. The resulting solution was stirred at $0{ }^{\circ} \mathrm{C}$ for $1 \mathrm{~h}$ and then warmed to $25^{\circ} \mathrm{C}$ and stirred for another $5 \mathrm{~h}$. The reaction was concentrated. The residue was dissolved in $50 \mathrm{~mL}$ of $\mathrm{CH}_{2} \mathrm{Cl}_{2}$ and the solution was washed with saturated $\mathrm{NaHCO}_{3}$ and brine, dried $\left(\mathrm{Na}_{2} \mathrm{SO}_{4}\right)$, and concentrated to give $1.93 \mathrm{~g}$ of crude 6-chloro-3-(chloromethyl)-2-fluoropyridine (10b), which was used without further purification. A small portion of crude $\mathbf{1 0 b}$ was recrystallized to give an analytical sample: ${ }^{1} \mathrm{H}$ NMR $7.85(\mathrm{dd}, 1, J=9.2,8.0), 7.28(\mathrm{~d}, 1, J=8.0), 4.59(\mathrm{~s}, 2) ;{ }^{13} \mathrm{C}$ NMR $159.4(\mathrm{~d}, J=246)$, $148.7(\mathrm{~d}, J=14), 143.2(\mathrm{~d}, J=4.5), 122.2(\mathrm{~d}, J=5.1), 118.2(\mathrm{~d}, J=28), 37.9 ;$ IR 1603, 1573, 1437, 1398; HRMS (EI) calcd for $\mathrm{C}_{6} \mathrm{H}_{4} \mathrm{NCl}_{2} \mathrm{~F}\left(\mathrm{M}^{+}\right)$178.9705, found 178.9710.

Powdered $\mathrm{NaCN}(1.10 \mathrm{~g}, 22.4 \mathrm{mmol})$ was added to $20 \mathrm{~mL}$ of DMSO. The mixture was stirred at $25^{\circ} \mathrm{C}$ for $20 \mathrm{~min}$. A solution of crude $10 \mathbf{b}$ in $5 \mathrm{~mL}$ of DMSO was added to the $\mathrm{NaCN}$ suspension dropwise over $10 \mathrm{~min}$. The $\mathrm{NaCN}$ fully dissolved after addition. The resulting solution was stirred for $1 \mathrm{~h}$ at $25^{\circ} \mathrm{C}$ and cooled to $0{ }^{\circ} \mathrm{C}$. Water $(100 \mathrm{~mL})$ was added slowly to the reaction and the mixture was extracted with $\mathrm{CH}_{2} \mathrm{Cl}_{2}(50 \mathrm{~mL} \times 3)$. The combined organic layers were washed with $\mathrm{H}_{2} \mathrm{O}$ and brine, dried $\left(\mathrm{Na}_{2} \mathrm{SO}_{4}\right)$, and concentrated to give $1.50 \mathrm{~g}$ of crude $\mathbf{1 1 b}$. Flash chromatography (6:1 hexanes/EtOAc to 3:1 hexanes/EtOAc) gave $1.23 \mathrm{~g}$ of pure $\mathbf{1 1 b}$. Recrystallization gave $1.10 \mathrm{~g}(63 \%)$ of analytically pure 11b: $R_{f}=0.37$ (3:1 hexanes/EtOAc); mp 47-48 ${ }^{\circ} \mathrm{C} ;{ }^{1} \mathrm{H}$ NMR $7.89(\mathrm{dd}, 1, J=9.2,8.0), 7.33(\mathrm{~d}, 1, J=8.0), 3.78(\mathrm{~s}, 2) ;{ }^{13} \mathrm{C}$ NMR $159.2(\mathrm{~d}$, $J=246), 148.9(\mathrm{~d}, J=14), 142.3(\mathrm{~d}, J=4.1), 122.4(\mathrm{~d}, J=5.3), 115.4,111.2(\mathrm{~d}, J=29), 17.2$; IR 2261; HRMS (EI) calcd for $\mathrm{C}_{7} \mathrm{H}_{4} \mathrm{~N}_{2} \mathrm{ClF}\left(\mathrm{M}^{+}\right)$170.0047, found 170.0055 .

6-Chloro-2-fluoro-3-pyridineacetamide (6b). A mixture of $\mathbf{1 1 b}$ (300 mg, $1.76 \mathrm{mmol}$ ) and alumina $(570 \mathrm{mg}, 5.59 \mathrm{mmol})$ in $\mathrm{MsOH}(5 \mathrm{~mL})$ was heated at $120{ }^{\circ} \mathrm{C}$ for $15 \mathrm{~min}$. The reaction was cooled and $\mathrm{H}_{2} \mathrm{O}(30 \mathrm{~mL})$ was added. The mixture was extracted with $\mathrm{CH}_{2} \mathrm{Cl}_{2}$ $(30 \mathrm{~mL} \times 5)$. The combined $\mathrm{CH}_{2} \mathrm{Cl}_{2}$ layers were washed with brine $(30 \mathrm{~mL})$, dried $\left(\mathrm{MgSO}_{4}\right)$, and concentrated to give $285 \mathrm{mg}$ of $\mathbf{6 b}$ as a white solid. Crude $\mathbf{6 b}$ was dissolved in the minimum amount of $\mathrm{MeOH}$ at $60{ }^{\circ} \mathrm{C}$ and the solution was cooled and hexanes were added to facilitate 
recrystallization. Needles crystallized slowly from the interface to give $201 \mathrm{mg}(61 \%)$ of pure $\mathbf{6 b}$ : mp 179-180 ${ }^{\circ} \mathrm{C} ;{ }^{1} \mathrm{H}$ NMR $\left(\mathrm{CD}_{3} \mathrm{OD}\right) 7.85(\mathrm{dd}, 1, J=9.2,8.0), 7.34(\mathrm{~d}, 1, J=8.0), 3.60(\mathrm{~s}, 2) ;{ }^{13} \mathrm{C}$ $\operatorname{NMR}\left(\mathrm{CD}_{3} \mathrm{OD}\right) 174.2,161.8(\mathrm{~d}, J=242), 148.0(\mathrm{~d}, J=14), 146.5(\mathrm{~d}, J=5.3), 123.1(\mathrm{~d}, J=5.3)$, $118.2(\mathrm{~d}, J=29), 35.3$; IR 3310, 3205, 1671; HRMS (ESI+) calcd for $\mathrm{C}_{7} \mathrm{H}_{7} \mathrm{~N}_{2} \mathrm{OClF}\left(\mathrm{MH}^{+}\right)$ 189.0231 , found 189.0233 .

6-Chloro-2-fluoro- $N$-(2-oxocyclobutyl)-3-pyridineacetamide (5b). Primary amide 6b (161 mg, $0.86 \mathrm{mmol})$ and 1,2-bis(trimethylsiloxy)cyclobutene $(7,256 \mathrm{mg}, 1.11 \mathrm{mmol})$ in $5 \mathrm{~mL}$ of saturated $\mathrm{HCl}$ in anhydrous ether was sealed in a resealable tube. The reaction was heated at $80{ }^{\circ} \mathrm{C}$ for $2 \mathrm{~h}$ and cooled to $25^{\circ} \mathrm{C}$. The solvent was removed and the residue was dissolved in $30 \mathrm{~mL}$ of $\mathrm{CH}_{2} \mathrm{Cl}_{2}$. The solution was washed with saturated $\mathrm{NaHCO}_{3}$ to remove the side product, 6-chloro-2-fluoro-3-pyridineacetic acid, and then brine, and dried $\left(\mathrm{Na}_{2} \mathrm{SO}_{4}\right)$. Concentration gave $219 \mathrm{mg}$ of a light brown solid. The crude product was washed with $5 \mathrm{~mL}$ of cold ether to give $186 \mathrm{mg}(85 \%)$ of pure $5 \mathbf{b}$ that was used directly for the next step: $R_{f}=0.23\left(20: 1 \mathrm{CH}_{2} \mathrm{Cl}_{2} / \mathrm{MeOH}\right)$; ${ }^{1} \mathrm{H}$ NMR 7.77 (dd, 1, $\left.J=9.2,8.0\right), 7.24$ (d, 1, $\left.J=8.0\right), 6.28$ (br d, 1, $\left.J=8.4, \mathrm{NH}\right), 4.93$ (ddd, 1, $J$ $=10.0,8.4,8.4), 3.54(\mathrm{~s}, 2), 2.96$ (apparent dd, $2, J=8.4,8.4, \mathrm{CH}_{2}$ group adjacent to ketone), 2.45 (dddd, $1, J=12.0,10.0,8.4,8.4), 2.07$ (dddd, $1, J=12.0,8.4,8.4,8.4) ;{ }^{13} \mathrm{C}$ NMR 204.8, $168.0,160.0(\mathrm{~d}, J=243), 147.6(\mathrm{~d}, J=14), 144.3(\mathrm{~d}, J=4.7), 122.1(\mathrm{~d}, J=5.1), 115.0(\mathrm{~d}, J=$ 29), 64.2, 42.2, 34.7, 19.5; IR 3307, 1782, 1650; HRMS (ESI+) calcd for $\mathrm{C}_{11} \mathrm{H}_{11} \mathrm{~N}_{2} \mathrm{O}_{2} \mathrm{ClF}\left(\mathrm{MH}^{+}\right)$ 257.0493, found 257.0492. Similar procedures have been reported for other primary amides. ${ }^{5 \mathrm{c}}$

(2aS,4aS,9aR)-rel-7-Chloro-1,2,2a,3,4,4a-hexahydrobenzofuro[2,3-c]cyclo-

buta[b]pyrrol-4-one (3). In a $100 \mathrm{~mL}$ flask, a suspension of amide $5 \mathbf{b}(86 \mathrm{mg}, 0.33 \mathrm{mmol})$ in $5 \mathrm{~mL}$ of $t-\mathrm{BuOH}$ was degassed using 3 freeze-thaw cycles. In another flask, $10 \mathrm{~mL}$ of $2 \mathrm{M}$ aqueous $\mathrm{KOH}$ was treated with ultrasound under vacuum for $30 \mathrm{~min}$. The degassed suspension of amide $5 \mathbf{b}$ was then treated with $3 \mathrm{~mL}$ of the degassed $2 \mathrm{M} \mathrm{KOH}$ solution $25^{\circ} \mathrm{C}$. The resulting reaction was stirred at $25{ }^{\circ} \mathrm{C}$ for $15 \mathrm{~min}$, and $5 \%$ aqueous citric acid was then added until the $\mathrm{pH}$ reached 6. The mixture was extracted with $\mathrm{CH}_{2} \mathrm{Cl}_{2}(3 \times 25 \mathrm{~mL})$. The combined organic layers were washed with brine, dried $\left(\mathrm{Na}_{2} \mathrm{SO}_{4}\right)$, and concentrated to give $82 \mathrm{mg}$ of crude lactam 3 . 
Flash chromatography $\left(30: 1 \mathrm{CH}_{2} \mathrm{Cl}_{2} / \mathrm{MeOH}\right)$ gave $37 \mathrm{mg}(46 \%)$ of pure lactam $3: R_{f}=0.33(20: 1$ $\mathrm{CH}_{2} \mathrm{Cl}_{2} / \mathrm{MeOH}$ ); $\mathrm{mp} 208-209{ }^{\circ} \mathrm{C}$ (decomposition); ${ }^{1} \mathrm{H}$ NMR 7.73 (dd, 1, J=7.6, 1.3), 6.92 (d, 1, $J=7.6), 6.29\left(\right.$ br s, $\left.1, \mathrm{w}_{1 / 2}=20, \mathrm{NH}\right), 4.38(\mathrm{dd}, 1, J=7,6), 4.05(\mathrm{~s}, 1), 2.81-2.68(\mathrm{~m}, 1), 2.54-$ 2.38 (m, 2), 1.72-1.60 (m, 1); ${ }^{13} \mathrm{C}$ NMR 175.5, 166.1, 149.9, 136.0, 117.3, 115.4, 89.0, 59.7, 52.1, 29.3, 24.8; IR 3380, 3271, 1690; HRMS (ESI+) calcd for $\mathrm{C}_{11} \mathrm{H}_{10} \mathrm{~N}_{2} \mathrm{O}_{2} \mathrm{Cl}\left(\mathrm{MH}^{+}\right)$237.0431, found 237.0430. The structure of 3 was confirmed by X-ray crystal structure determination.

X-Ray data collection, solution, and refinement for Lactam 3. All operations were performed on a Bruker-Nonius Kappa Apex2 diffractometer, using graphite-monochromated MoK $\alpha$ radiation. All diffractometer manipulations, including data collection, integration, scaling, and absorption corrections were carried out using the Bruker Apex 2 software. ${ }^{\mathrm{S} 1}$ Preliminary cell constants were obtained from three sets of 12 frames. Data collection was carried out at 120K, using a frame time of $10 \mathrm{sec}$ and a detector distance of $60 \mathrm{~mm}$. The optimized strategy used for data collection consisted of six phi and three omega scan sets, with $0.5^{\circ}$ steps in phi or omega; completeness was $100.0 \%$. A total of 3900 frames were collected. Final cell constants were obtained from the xyz centroids of 8153 reflections after integration.

From the systematic absences, the observed metric constants and intensity statistics, space group $P 2_{1} / n$ was chosen initially; subsequent solution and refinement confirmed the correctness of this choice. The structure was solved using SuperFlip, ${ }^{\text {S2 }}$ and refined (full-matrixleast squares) using the Oxford University Crystals for Windows program. ${ }^{\text {S3 }}$ All ordered nonhydrogen atoms were refined using anisotropic displacement parameters. Hydrogen atoms were refined using isotropic displacement parameters. The final least-squares refinement converged to $\mathrm{R}_{1}=0.0306(I>2 \sigma(I), 2893$ data $)$ and $\mathrm{wR}_{2}=0.0817\left(F^{2}, 2992\right.$ data, 181 parameters $)$. The relative stereochemistry of a single enantiomer (the crystal is a racemic mixture) is $R, S, R$ for atoms $\mathrm{C}(6), \mathrm{C}(7)$ and $\mathrm{C}(8)$, respectively.

(2aS,4aR,9aR)-rel-7-Chloro-1,2,2a,3,4,4a-hexahydrobenzofuro[2,3c]cyclobuta[b]pyrrole (Phantasmidine, 1). A solution of lactam 3 (34 mg, $0.14 \mathrm{mmol})$ in $1 \mathrm{~mL}$ of anhydrous THF was treated with $3 \mathrm{~mL}$ of $1 \mathrm{M} \mathrm{BH}_{3} \bullet \mathrm{THF}$ in THF dropwise over 5 min at $0{ }^{\circ} \mathrm{C}$. 
After addition, the reaction was slowly warmed to $25^{\circ} \mathrm{C}$ and stirred at that temperature for $30 \mathrm{~h}$. The reaction was cooled to $0^{\circ} \mathrm{C}$ and $2 \mathrm{~mL}$ of $\mathrm{MeOH}$ was added dropwise over $5 \mathrm{~min}$. The reaction was warmed to $25^{\circ} \mathrm{C}$ and then concentrated. The residue was treated with $4 \mathrm{~mL}$ of $\mathrm{MeOH}$ and concentrated to give $48 \mathrm{mg}$ of a mixture of $\mathbf{1}, \mathbf{1} \cdot \mathrm{BH}_{3}$ and $\mathbf{1} \cdot 2 \mathrm{BH}_{3}$. The crude mixture was dissolved in $5 \mathrm{~mL}$ of $\mathrm{MeOH}$ and treated with $387 \mathrm{mg}$ of piperazine. The resulting solution was heated at gentle reflux for $3 \mathrm{~h}$ and cooled. The reaction was concentrated and the residue was dissolved in $30 \mathrm{~mL}$ of $\mathrm{CH}_{2} \mathrm{Cl}_{2}$. The solution was washed with $\mathrm{H}_{2} \mathrm{O}(3 \times 20 \mathrm{~mL})$ and brine, dried $\left(\mathrm{Na}_{2} \mathrm{SO}_{4}\right)$, and concentrated to give $32 \mathrm{mg}$ of crude 1. Crude 1 was dissolved $10 \mathrm{~mL}$ of $4 \%$ aqueous $\mathrm{HCl}$ and the resulting solution was washed with $\mathrm{CH}_{2} \mathrm{Cl}_{2}(2 \times 5 \mathrm{~mL})$. The aqueous layer was treated with $2 \mathrm{M}$ aqueous $\mathrm{Na}_{2} \mathrm{CO}_{3}$ slowly until the $\mathrm{pH}$ reached 10 and extracted with $\mathrm{CH}_{2} \mathrm{Cl}_{2}$ $(3 \times 15 \mathrm{~mL})$. The combined organic layers were washed with brine, dried $\left(\mathrm{Na}_{2} \mathrm{SO}_{4}\right)$, and concentrated to give $22 \mathrm{mg}(67 \%)$ of pure 1: $R_{f}=0.24\left(20: 1 \mathrm{CH}_{2} \mathrm{Cl}_{2} / \mathrm{MeOH}\right) ;{ }^{1} \mathrm{H} \mathrm{NMR}\left(\mathrm{CD}_{3} \mathrm{OD}\right)$ $7.64(\mathrm{dd}, 1, J=7.6,1), 6.95$ (d, 1, $J=7.6), 4.01$ (dd, 1, $J=9,7), 3.84$ (br d, 1, J = 7.2), 3.67 (dd, $1, J=12.4,7.2), 3.45$ (br d, 1, $J=12.4), 2.50(\mathrm{ddd}, 1, J=12.4,12,9.5), 2.23$ (ddd, 1, $J=12.4$, 9.5, 3), 2.09 (dddd, 1, $J=12,12,9,3), 1.58$ (dddd, $1, J=12,9.5,9.5,7) ;{ }^{13} \mathrm{C} \mathrm{NMR}\left(\mathrm{CD}_{3} \mathrm{OD}\right)$ 168.2, 149.3, 137.8, 123.2, 118.1, 99.3, 67.4, 53.6, 51.4, 27.0, 17.8; IR 3287, 1593, 1598, 1416; HRMS (ESI+) calcd for $\mathrm{C}_{11} \mathrm{H}_{12} \mathrm{~N}_{2} \mathrm{OCl}\left(\mathrm{MH}^{+}\right)$223.0638, found 223.0639.

A solution of 1 in $\mathrm{CD}_{3} \mathrm{OD}$ was treated with a solution of TFA in $\mathrm{CD}_{3} \mathrm{OD}$. The ${ }^{1} \mathrm{H} \mathrm{NMR}$ spectrum of a sample containing 1 equivalent of TFA (monocation) matched that reported for phantasmidine: ${ }^{3}{ }^{1} \mathrm{H}$ NMR ( $\left.\mathrm{CD}_{3} \mathrm{OD}\right) 7.70$ (d, 1, J=8.0), 7.01 (d, 1, J=8.0), 4.24 (apparent br t, 1, $J \sim 7$ ), 4.07 (br d, 1, $J=6.8$ ), 3.92 (br dd, 1, $J=12.4,6.8$ ), 3.69 (d, 1, J=12.4), 2.63 (apparent q, 1, $J \sim 11$ ), 2.37 (apparent t, 1, $J \sim 11$ ), 2.22 (apparent qd, 1, $J \sim 11,3$ ), 1.74 (apparent qd, 1, $J=$ $11,7) ;{ }^{13} \mathrm{C}$ NMR (CD 3 OD) 167.9, 150.1, 138.2, 121.7, 118.7, 96.7, 65.8, 52.6, 50.3, 27.5, 16.3.

The enantiomers were separated by HPLC on an Agilent 1100 Series instrument equipped with a quaternary pump using a Daicel Chiralcel OJ-H column (250 x $4.6 \mathrm{~mm})$ eluting with 80:20 hexane/isopropanol at a flow rate of $1 \mathrm{~mL} / \mathrm{min}$ and monitoring at $230 \mathrm{~nm}$. Fifteen runs injecting $0.15 \mathrm{mg}$ of racemic phantasmidine gave a total of about $1 \mathrm{mg}$ of each enantiomer. 
The faster eluting isomer eluted at $27 \mathrm{~min}:[\theta]_{220}=140^{\circ},[\theta]_{320}=-140^{\circ}$. The slower eluting isomer eluted at $40 \mathrm{~min} ;[\theta]_{220}=-510^{\circ},[\theta]_{320}=+560^{\circ}$. The values should be equal and opposite, but are not because of weighing/transferring errors with small amounts of material.

1-[(2aS,4aR,9aR)-rel-7-chloro-2,2a,4,4a-tetrahydrobenzofuro[2,3-c]cyclobuta[b]pyrrol-3(1H)-yl]-ethanone ( $N$-Acetylphantasmidine, 17). A solution of phantasmidine (5 mg, $22 \mu \mathrm{mol})$ in $2 \mathrm{~mL}$ of anhydrous $\mathrm{CH}_{2} \mathrm{Cl}_{2}$ was treated with $\mathrm{NEt}_{3}(45 \mu \mathrm{L}, 0.22 \mathrm{mmol})$ followed by $\mathrm{AcCl}(16 \mu \mathrm{L}, 0.22 \mathrm{mmol})$ at $-15{ }^{\circ} \mathrm{C}$. The reaction was stirred at that temperature for $30 \mathrm{~min}$. The reaction was warmed to $25^{\circ} \mathrm{C}$ and stirred for another $30 \mathrm{~min}$. The reaction was cooled to $0{ }^{\circ} \mathrm{C}$ and $\mathrm{MeOH}(0.5 \mathrm{~mL})$ was added. The reaction was warmed to $25^{\circ} \mathrm{C}$ and diluted with $\mathrm{CH}_{2} \mathrm{Cl}_{2}$. The solution was washed with $\mathrm{H}_{2} \mathrm{O}$ and brine and dried $\left(\mathrm{Na}_{2} \mathrm{SO}_{4}\right)$. Concentration gave $7 \mathrm{mg}$ of crude 17. Flash chromatography $\left(40: 1 \mathrm{CH}_{2} \mathrm{Cl}_{2} / \mathrm{MeOH}\right)$ gave $4 \mathrm{mg}(67 \%)$ of pure 17 (a 2:1 mixture of rotamers): ${ }^{1} \mathrm{H} \mathrm{NMR}\left(\mathrm{CD}_{3} \mathrm{OD}\right.$, major) $7.70(\mathrm{dd}, 1, J=8.0,1.2) 6.99(\mathrm{~d}, 1, J=8.0)$, $4.71(\mathrm{dd}, 1, J=6.8,6.8), 4.11-4.07(\mathrm{~m}, 2), 4.03(\mathrm{dd}, 1, J=11.6,7.0), 2.56-2.34(\mathrm{~m}, 3), 2.01(\mathrm{~s}, 3)$, 1.74-1.66 (m, 1); ${ }^{1} \mathrm{H}$ NMR ( $\mathrm{CD}_{3} \mathrm{OD}$, minor) 7.73 (d, 1, J = 8.0, 1.2), 7.01 (d, 1, J=8.0), 4.80 (dd, $1, J=6.8,6.8), 4.32(\mathrm{dd}, 1, J=11.6,8.4), 4.15$ (br dd, $1, J=8.4,3.2), 3.97$ (dd, 1, $J=11.6,3.2)$, 2.56-2.34 (m, 3), $2.00(\mathrm{~s}, 3), 1.65-1.58(\mathrm{~m}, 1) ;{ }^{13} \mathrm{C}$ NMR (CD $\mathrm{OD}$, major) $171.5(\mathrm{C}), 167.7(\mathrm{C})$, $150.0(\mathrm{C}), 138.21(\mathrm{CH}), 123.0(\mathrm{C}), 118.6(\mathrm{CH}), 97.5(\mathrm{C}), 65.2(\mathrm{CH}), 53.4\left(\mathrm{CH}_{2}\right), 48.6(\mathrm{CH}), 27.7$ $\left(\mathrm{CH}_{2}\right), 22.12\left(\mathrm{CH}_{3}\right), 20.4\left(\mathrm{CH}_{2}\right) ;{ }^{13} \mathrm{C} \mathrm{NMR}\left(\mathrm{CD}_{3} \mathrm{OD}\right.$, minor) $171.5(\mathrm{C}), 166.9(\mathrm{C}), 150.1(\mathrm{C})$, $138.25(\mathrm{CH}), 123.0(\mathrm{C}), 118.6(\mathrm{CH}), 95.9(\mathrm{C}), 63.6(\mathrm{CH}), 55.0\left(\mathrm{CH}_{2}\right), 50.0(\mathrm{CH}), 28.2\left(\mathrm{CH}_{2}\right)$, $22.15\left(\mathrm{CH}_{3}\right), 20.2\left(\mathrm{CH}_{2}\right)$.

\section{References and Notes}

S1 Apex2, Version 2 User Manual, M86-E01078; Bruker Analytical X-ray Systems: Madison, WI, June 2006.

S2. Altomare, A; Cascarano, G; Giacovazzo, G.; Guagliardi, A.; Burla, M. C.; Polidori, G.; Camalli, M. J. Appl. Cryst. 1994, 27, 435.

S3. Betteridge, P. W.; Carruthers, J. R.; Cooper, R. I.; Prout, K.; Watkin, D. J. J. Appl. Cryst. 2003, 36, 1487. 
$\frac{\text { Synthesis of Phantasmidine }}{\text { Datablock quan_7.120.5. ellipsoid plot }}$

Zhou and Snider

$\underline{\text { Page S11 }}$

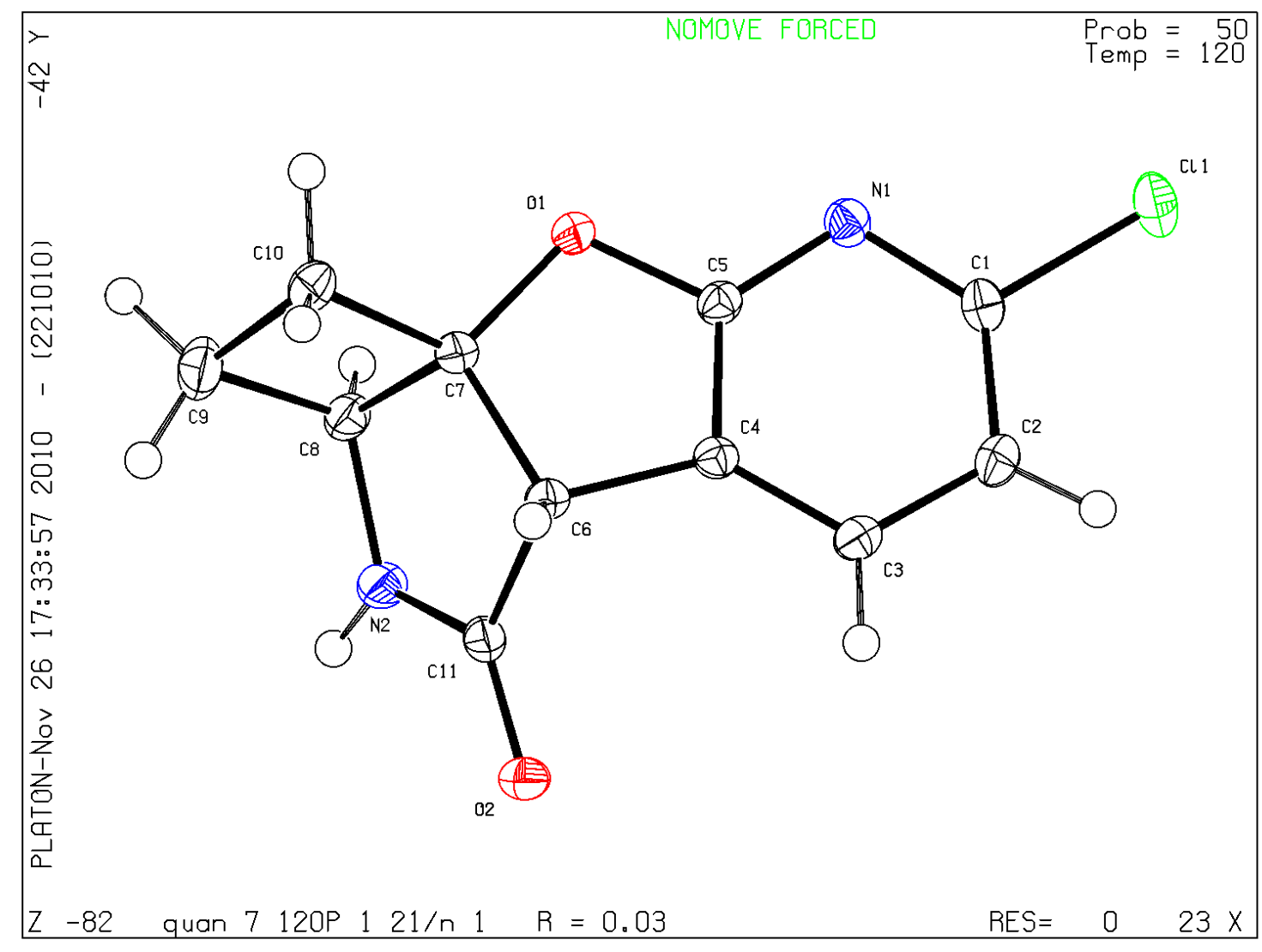


Synthesis of Phantasmidine

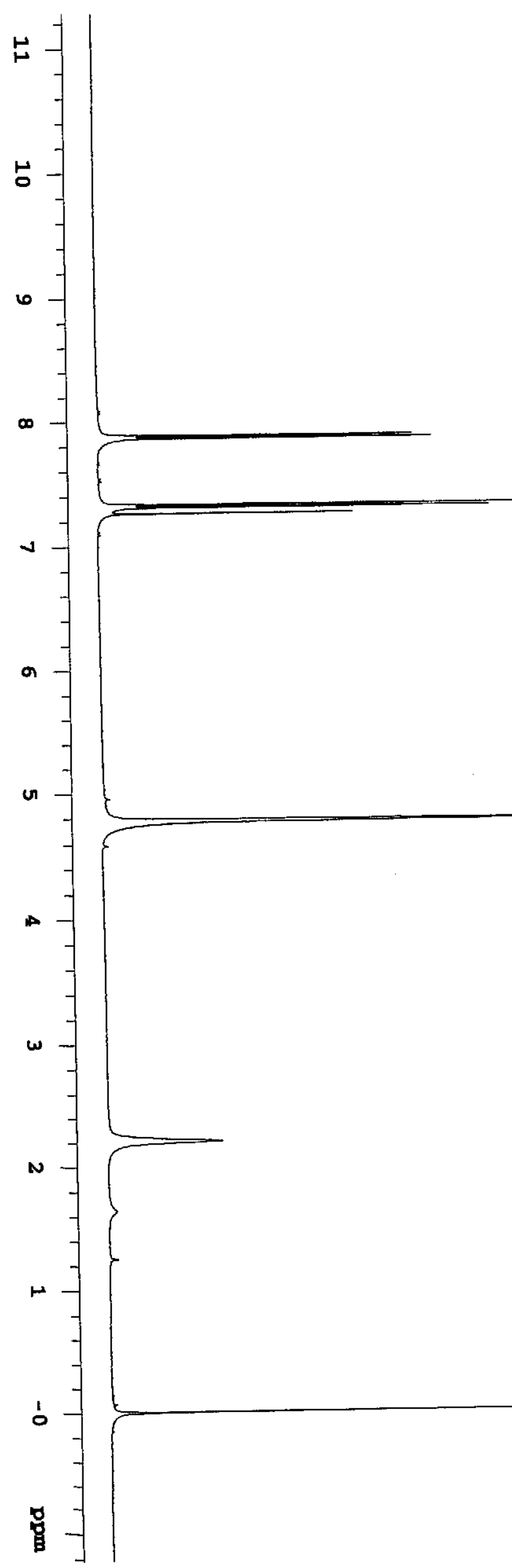

Zhou and Snider

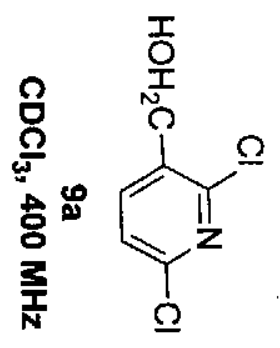




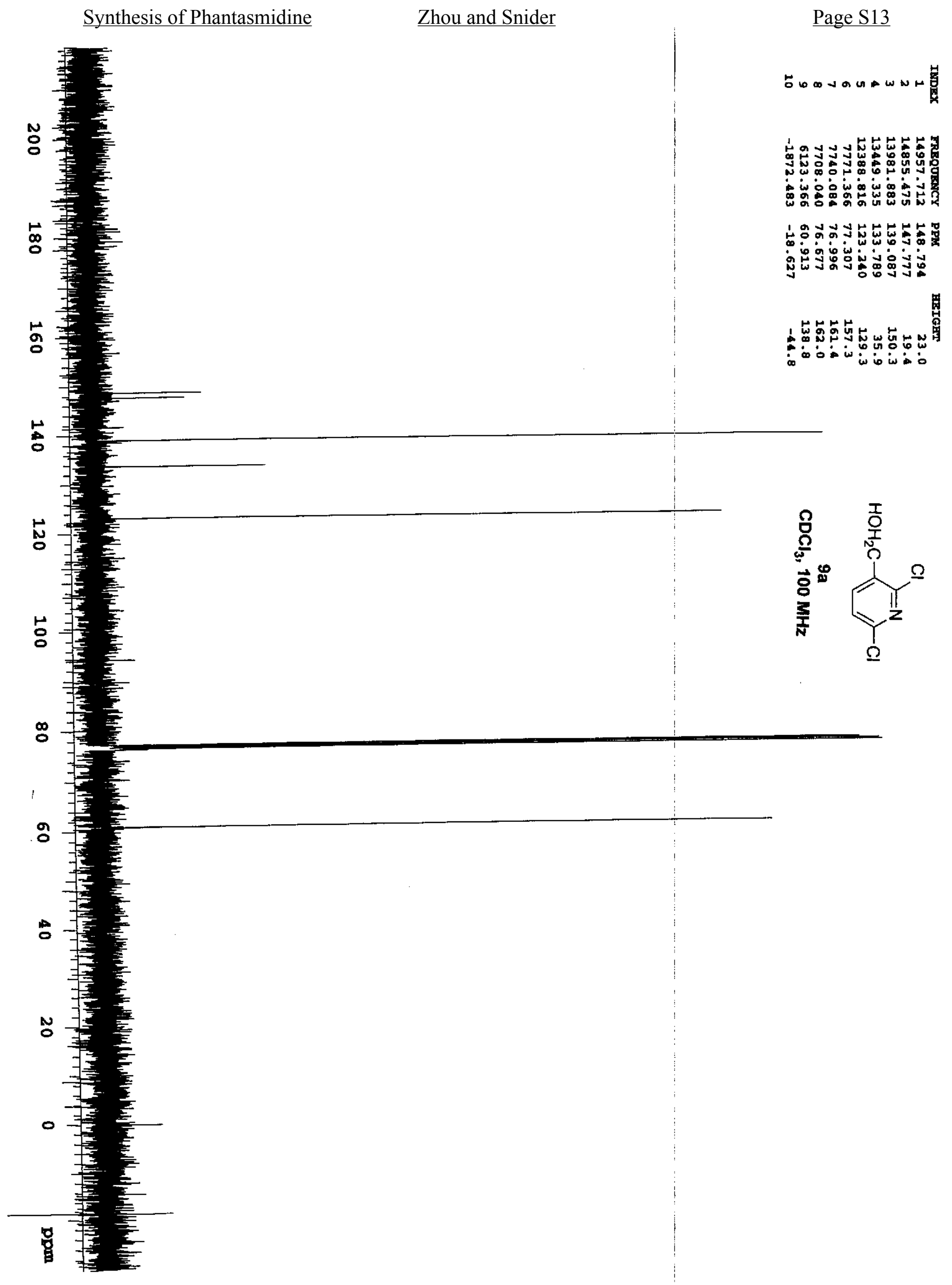


Synthesis of Phantasmidine

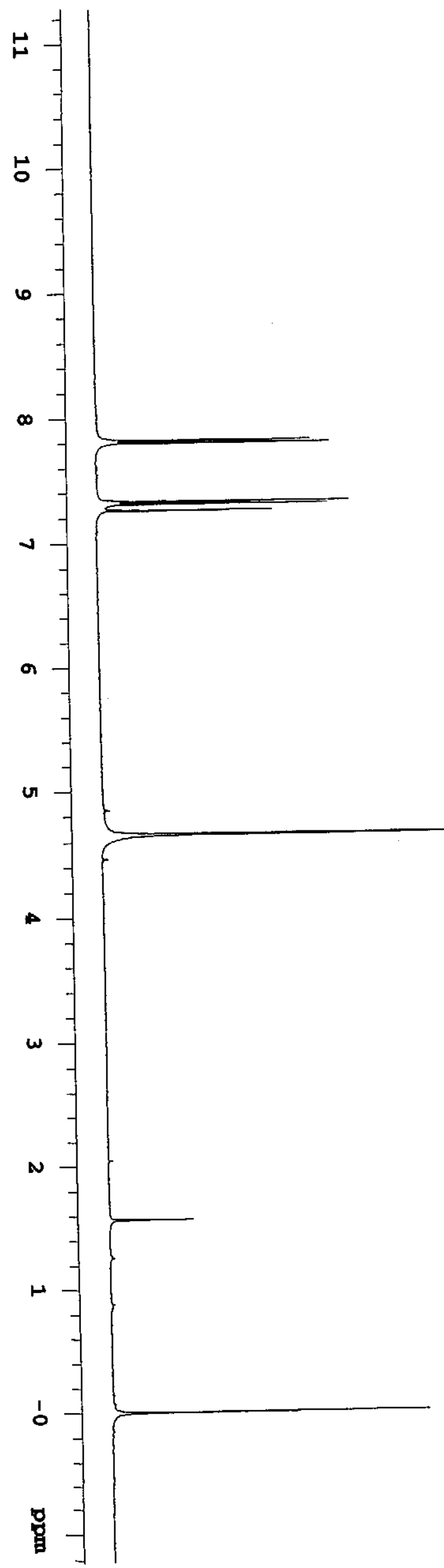

Chou and Snider

Page S14

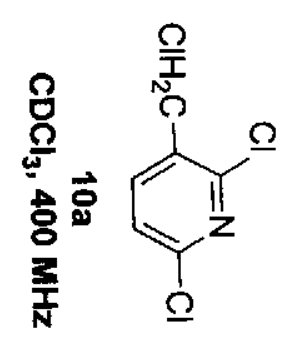


Synthesis of Phantasmidine

Zhou and Snider

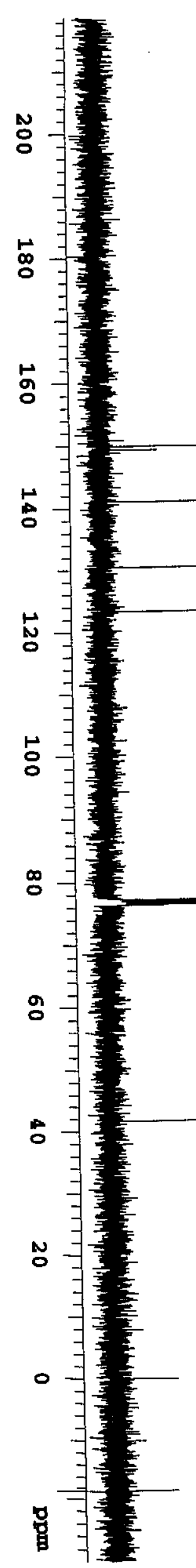

\section{Page S15}

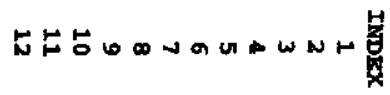

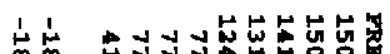

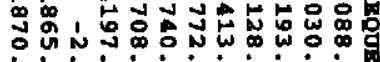

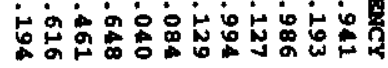

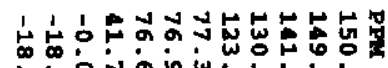

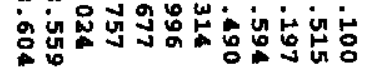

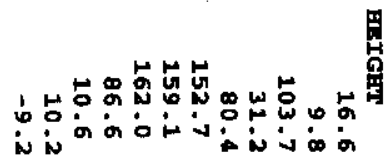<smiles>[2H]Oc1ccc(O)cc1O</smiles> 
Synthesis of Phantasmidine

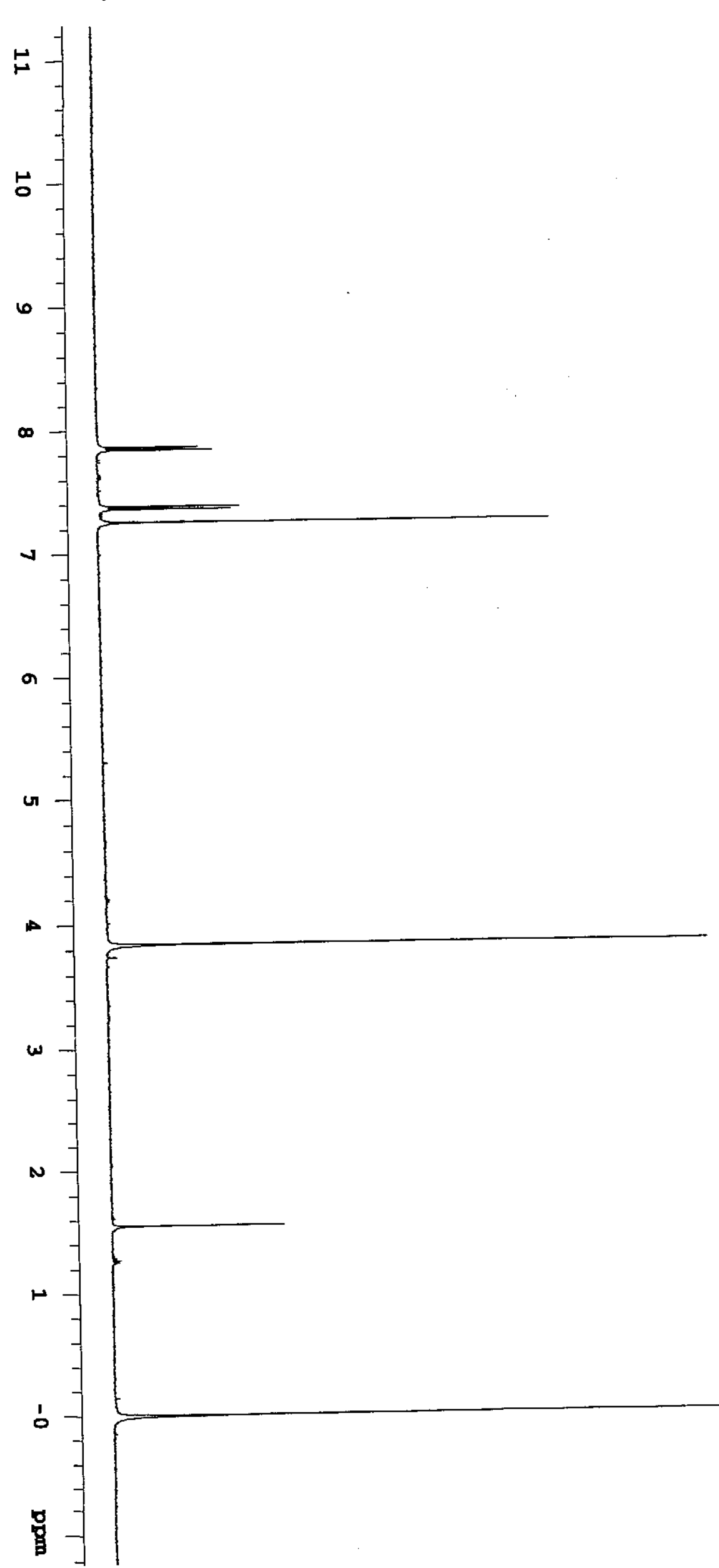

Page S16

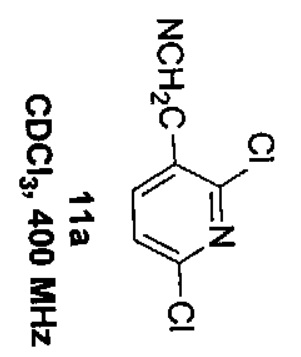




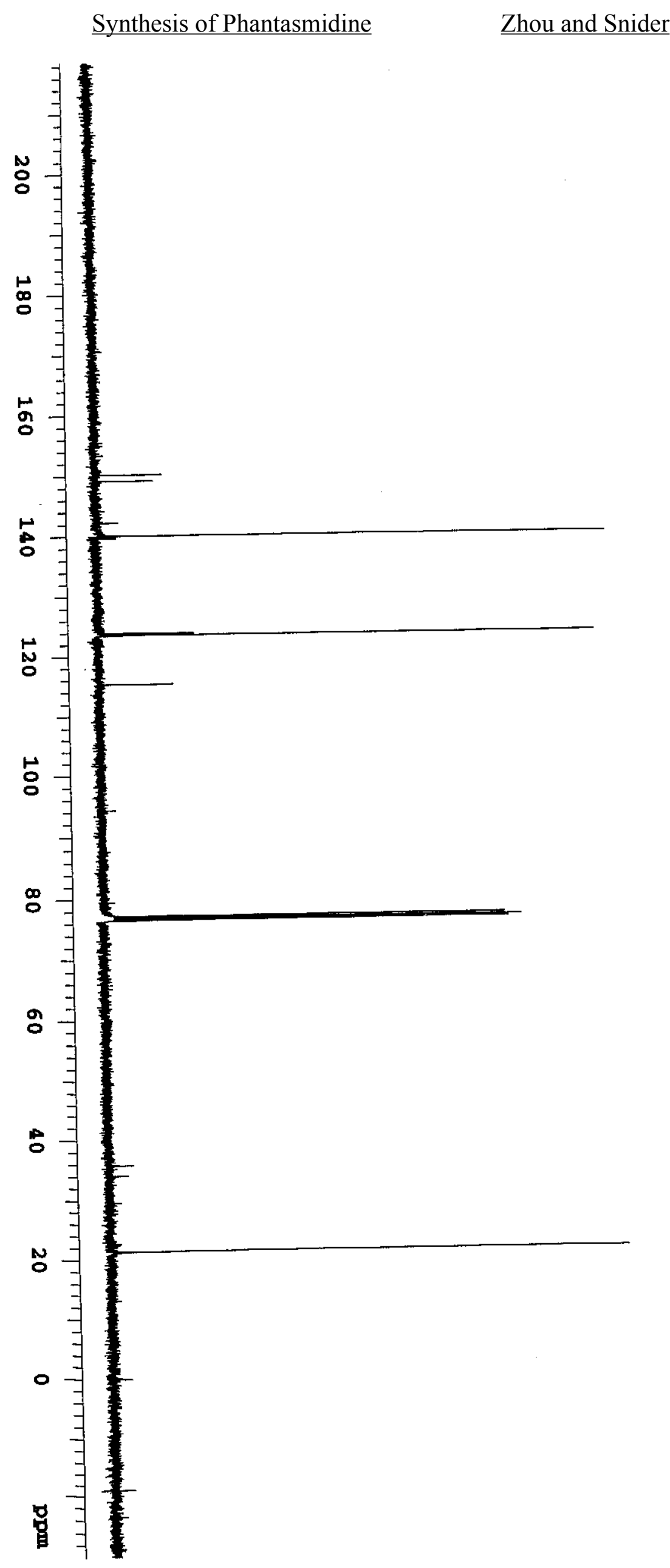




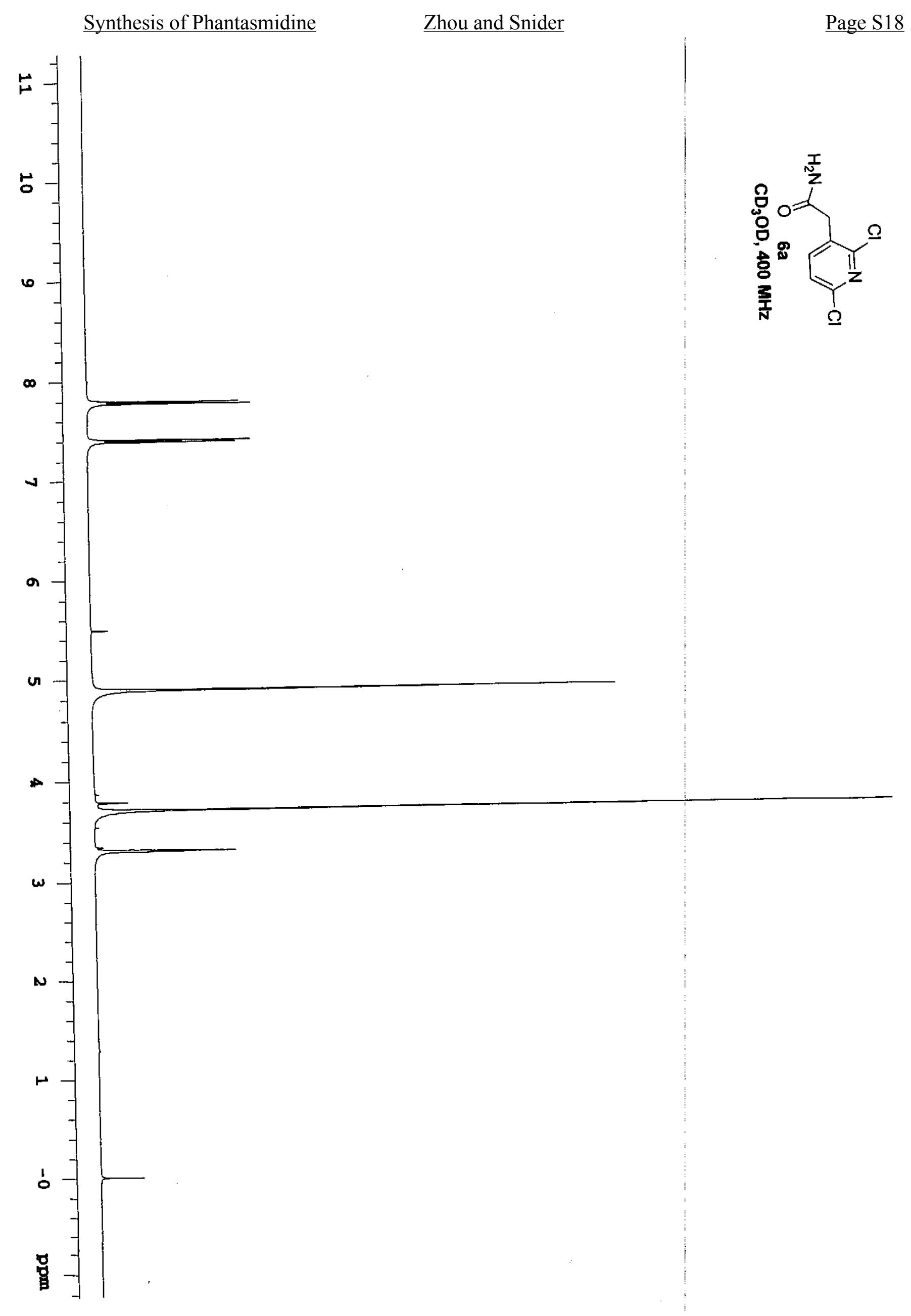


Synthesis of Phantasmidine

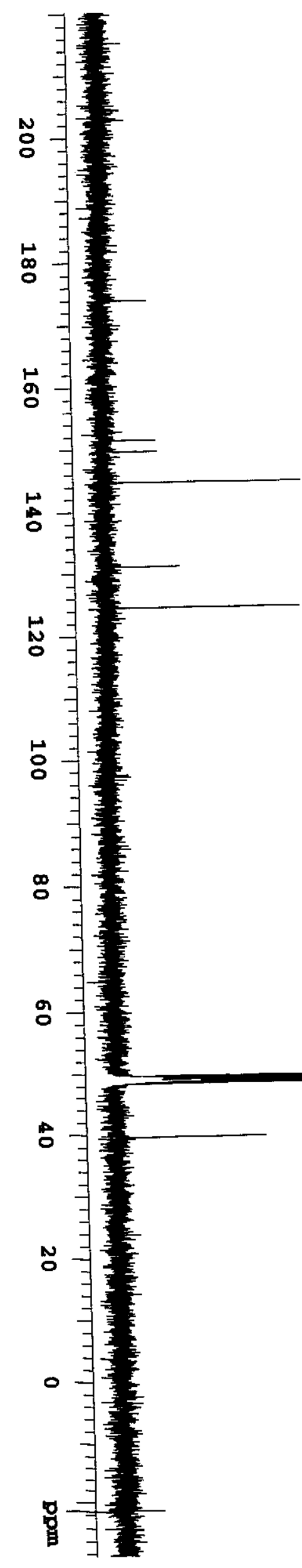

Zhou and Snider

Page S19

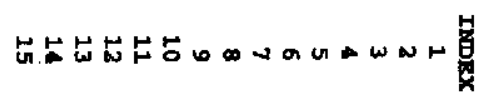

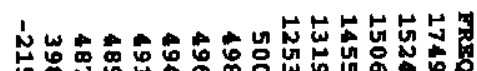

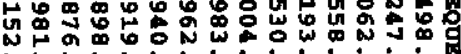

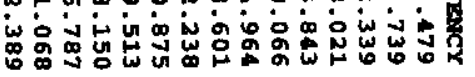

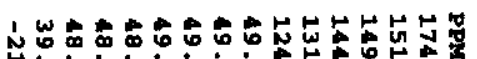

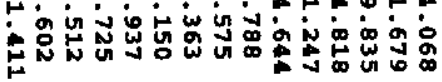

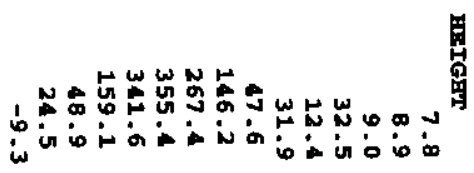

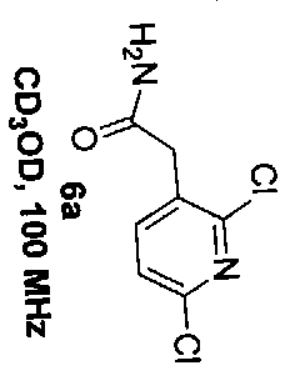



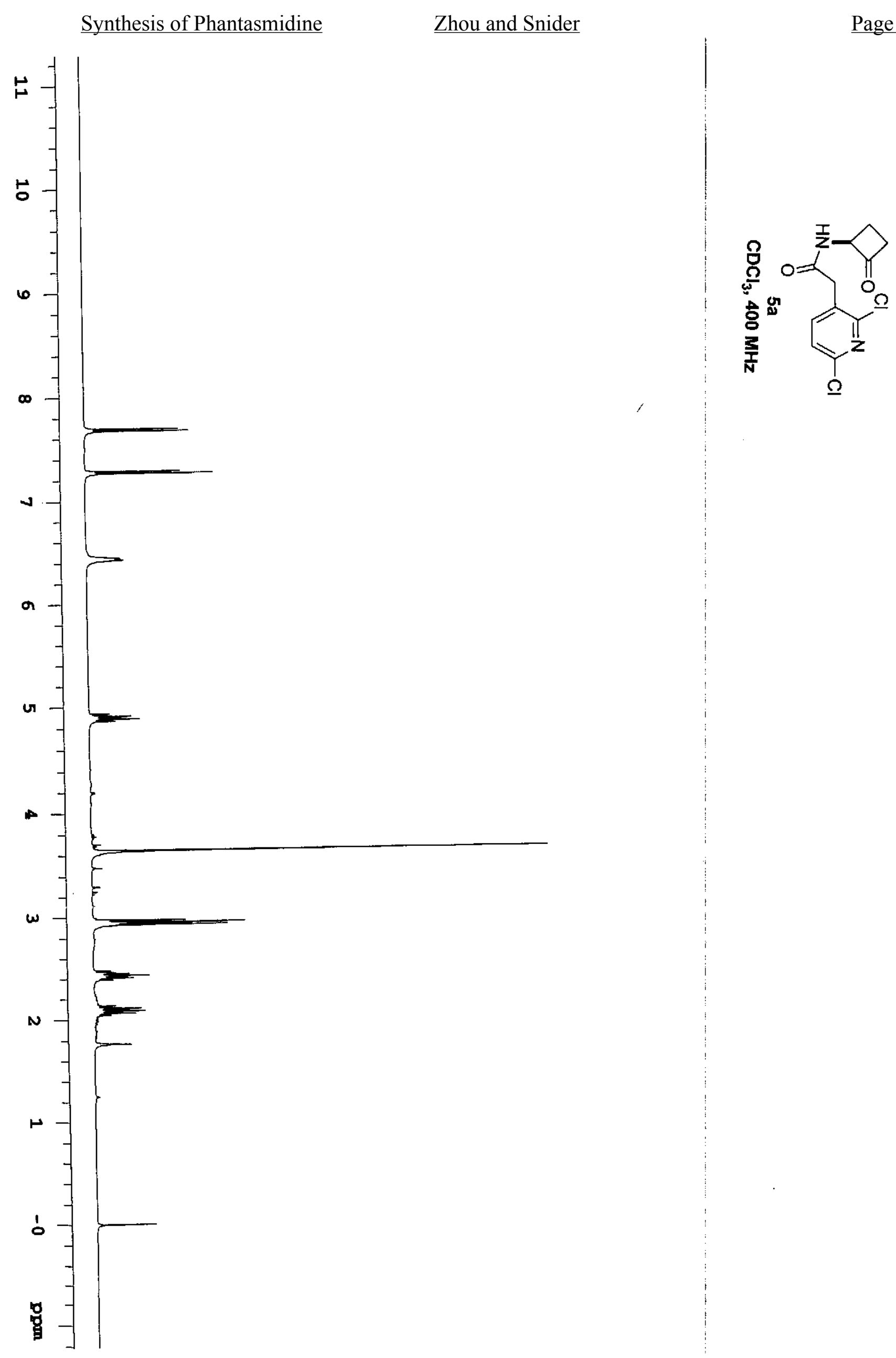


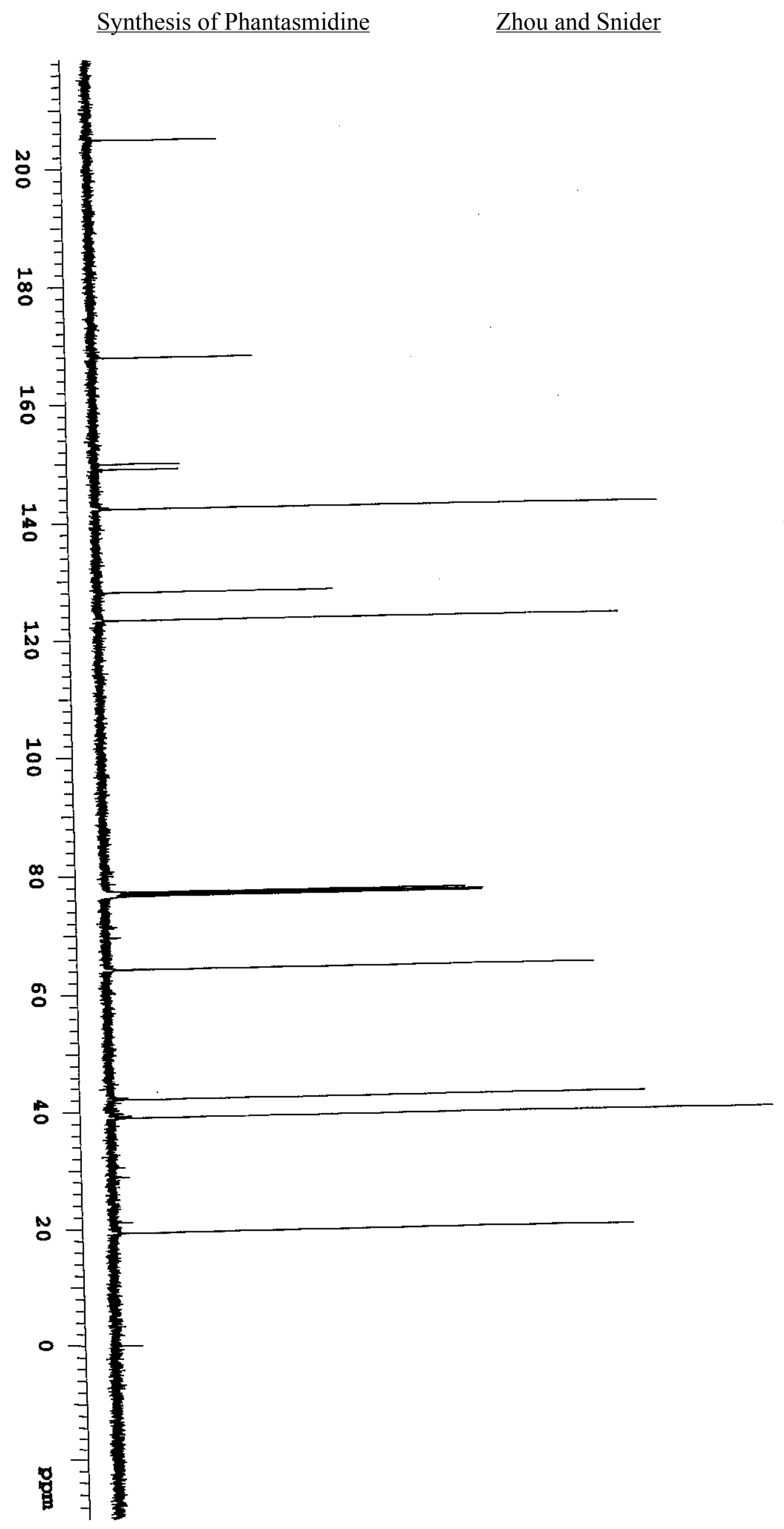

Page S21

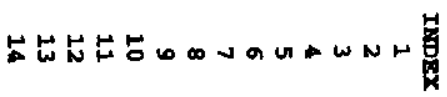

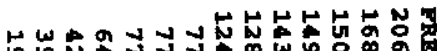

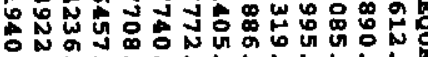

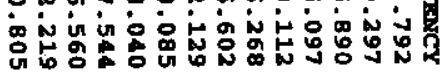

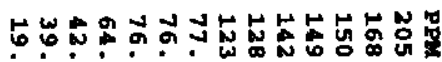

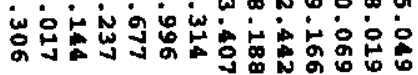

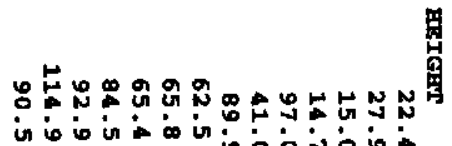

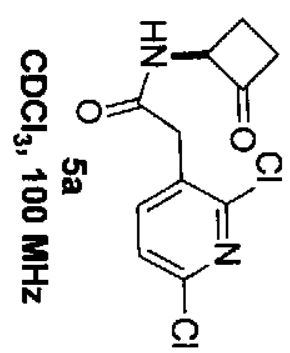




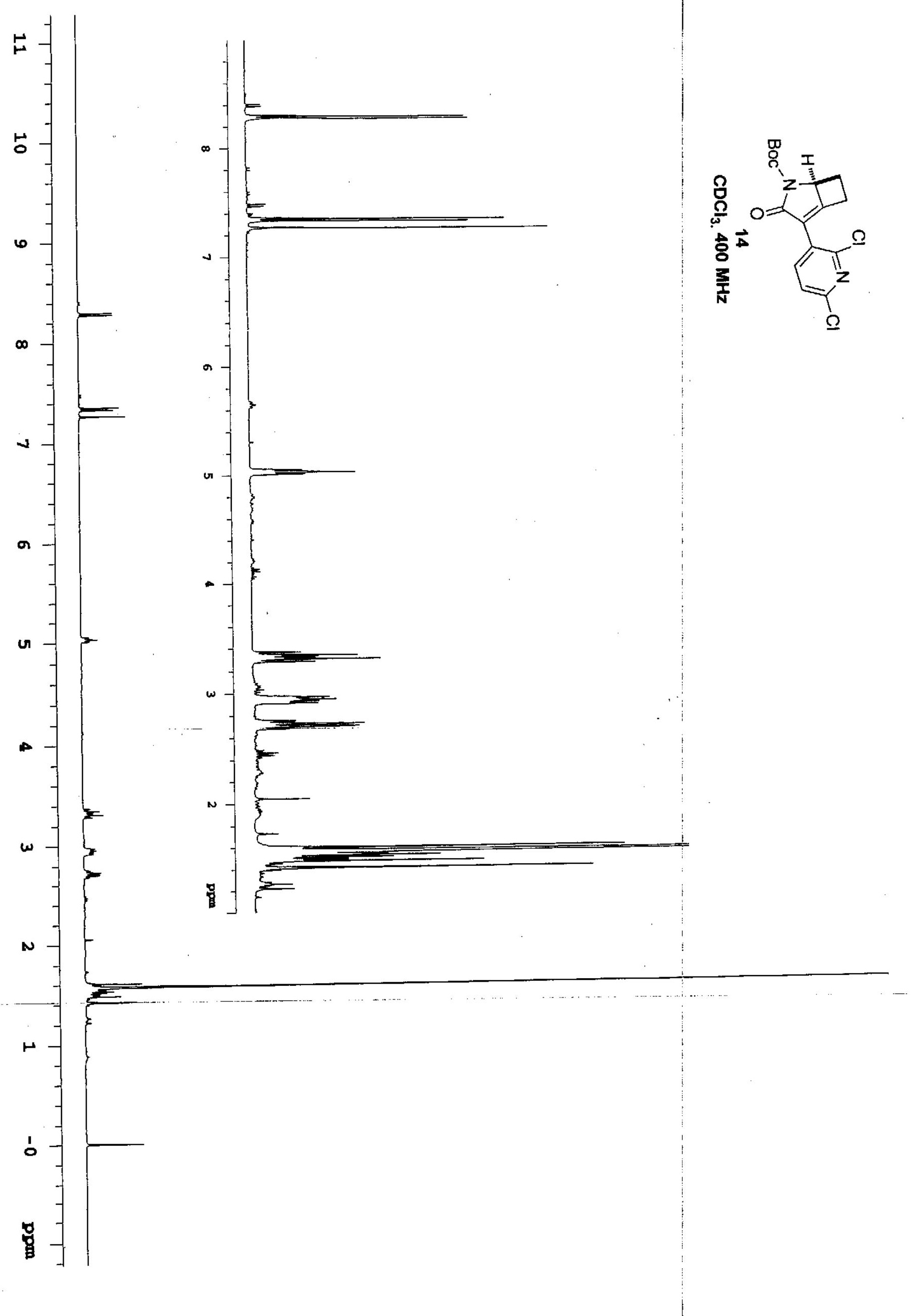


Synthesis of Phantasmidine

Zhou and Snider

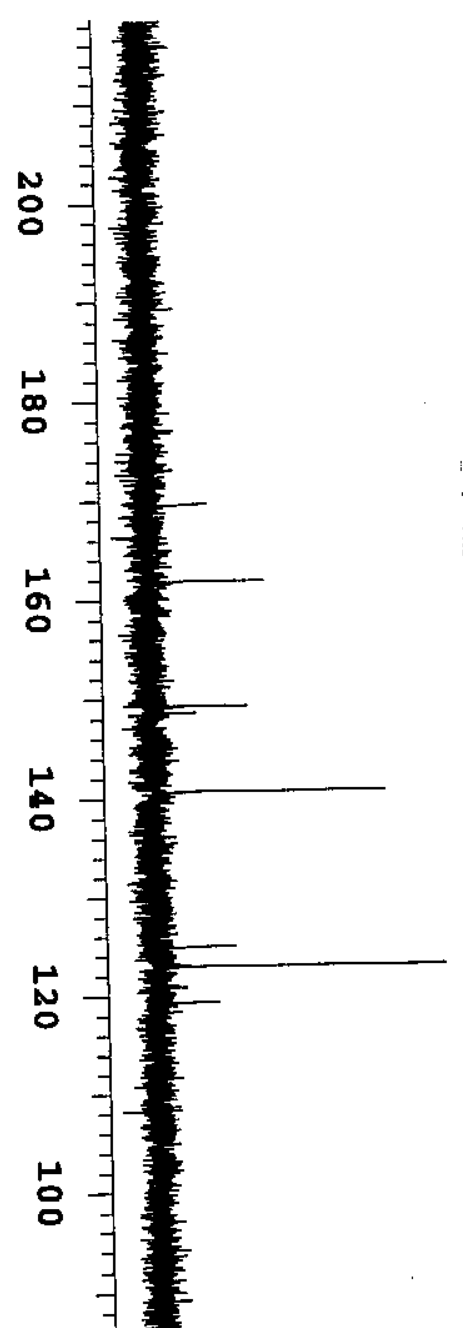

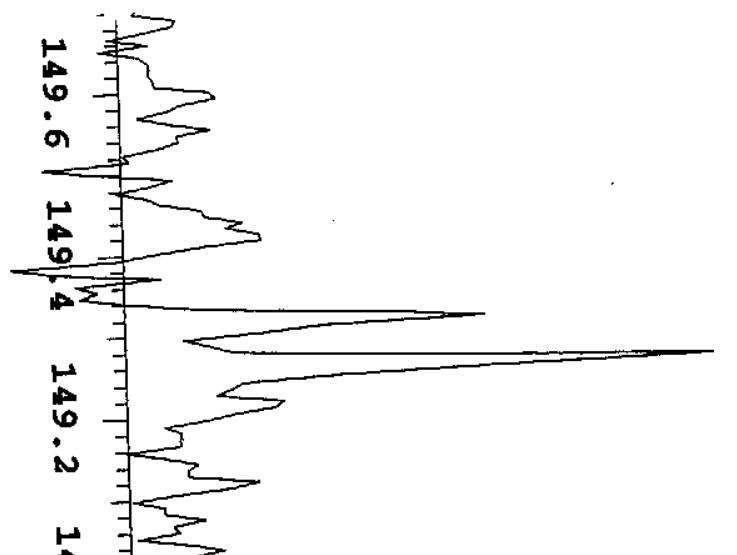

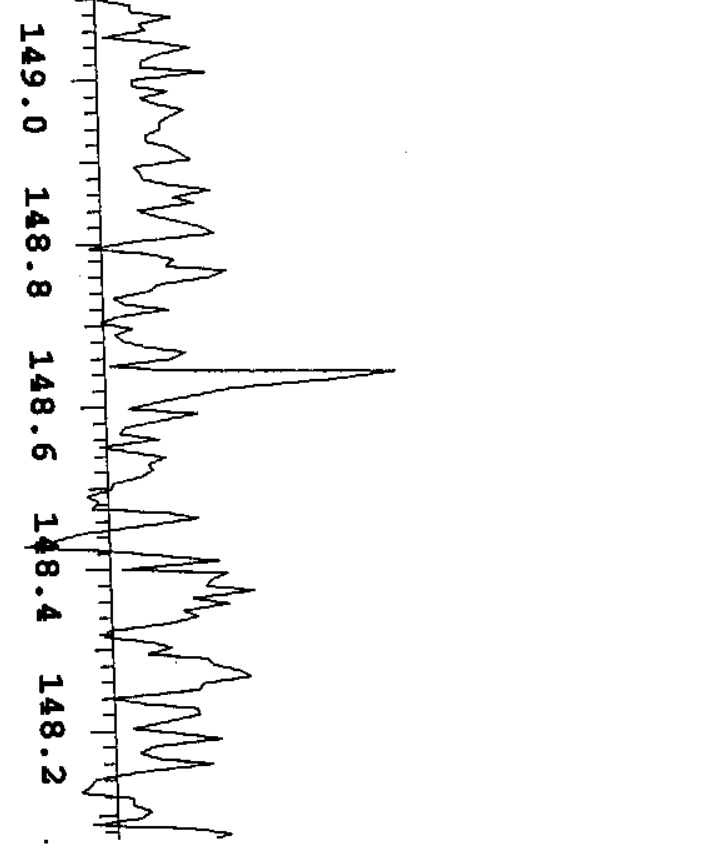

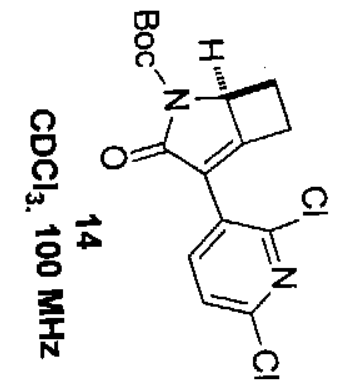


Synthesis of Phantasmidine

$\underline{\text { Zhou and Snider }}$

Page S24

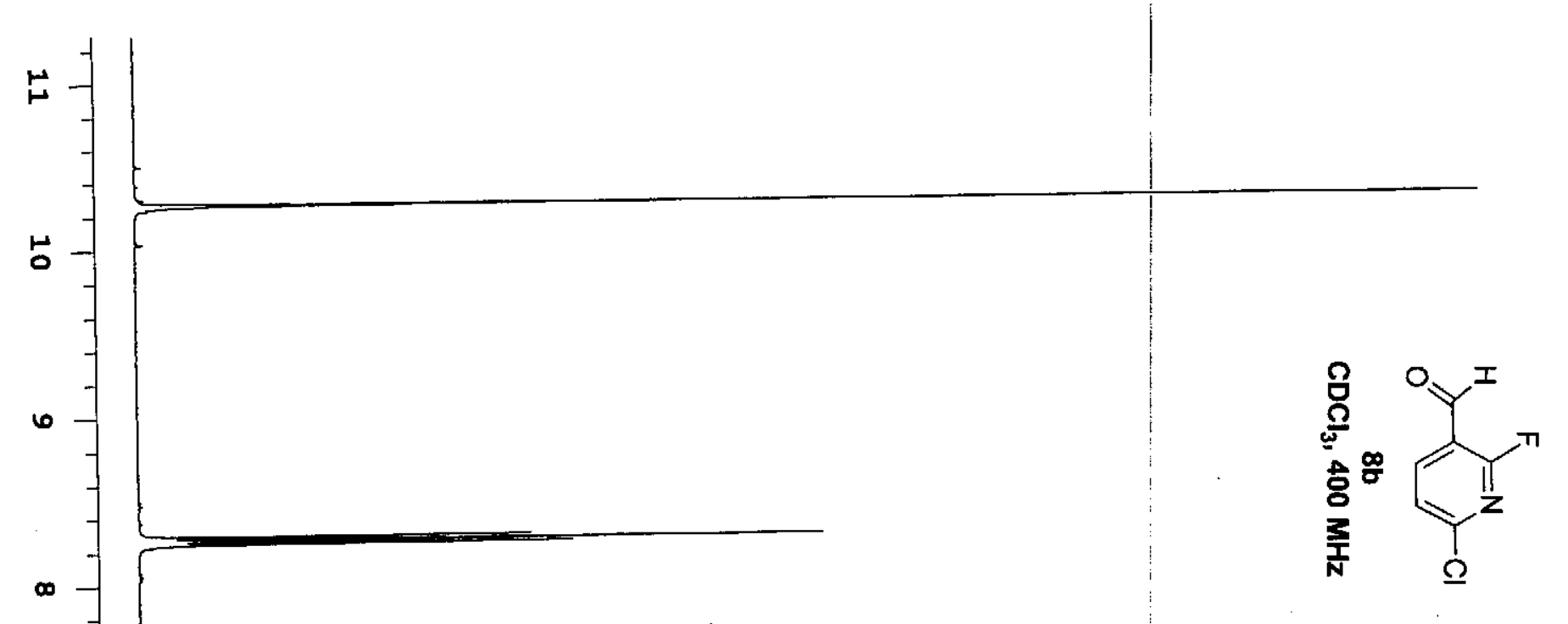




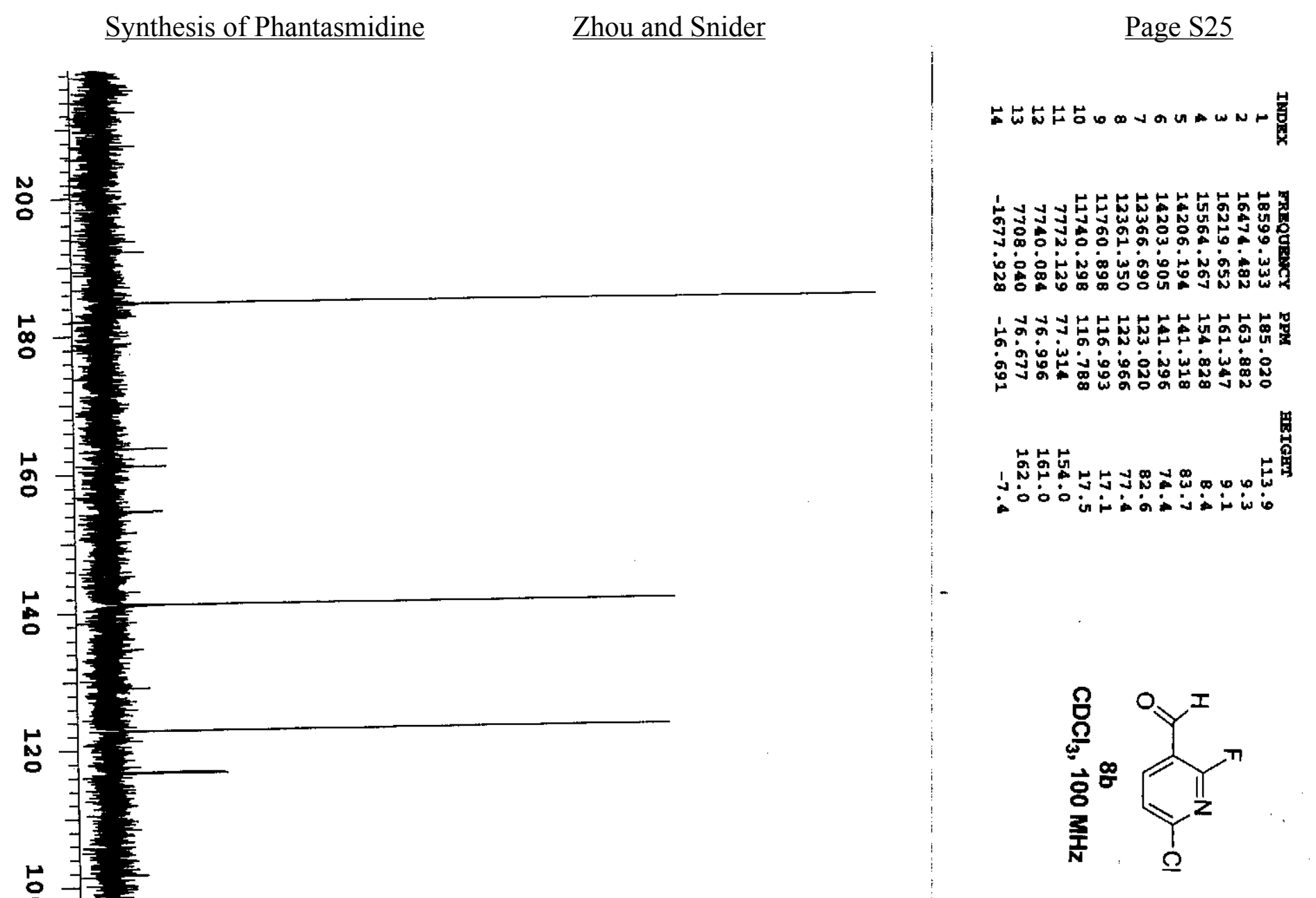



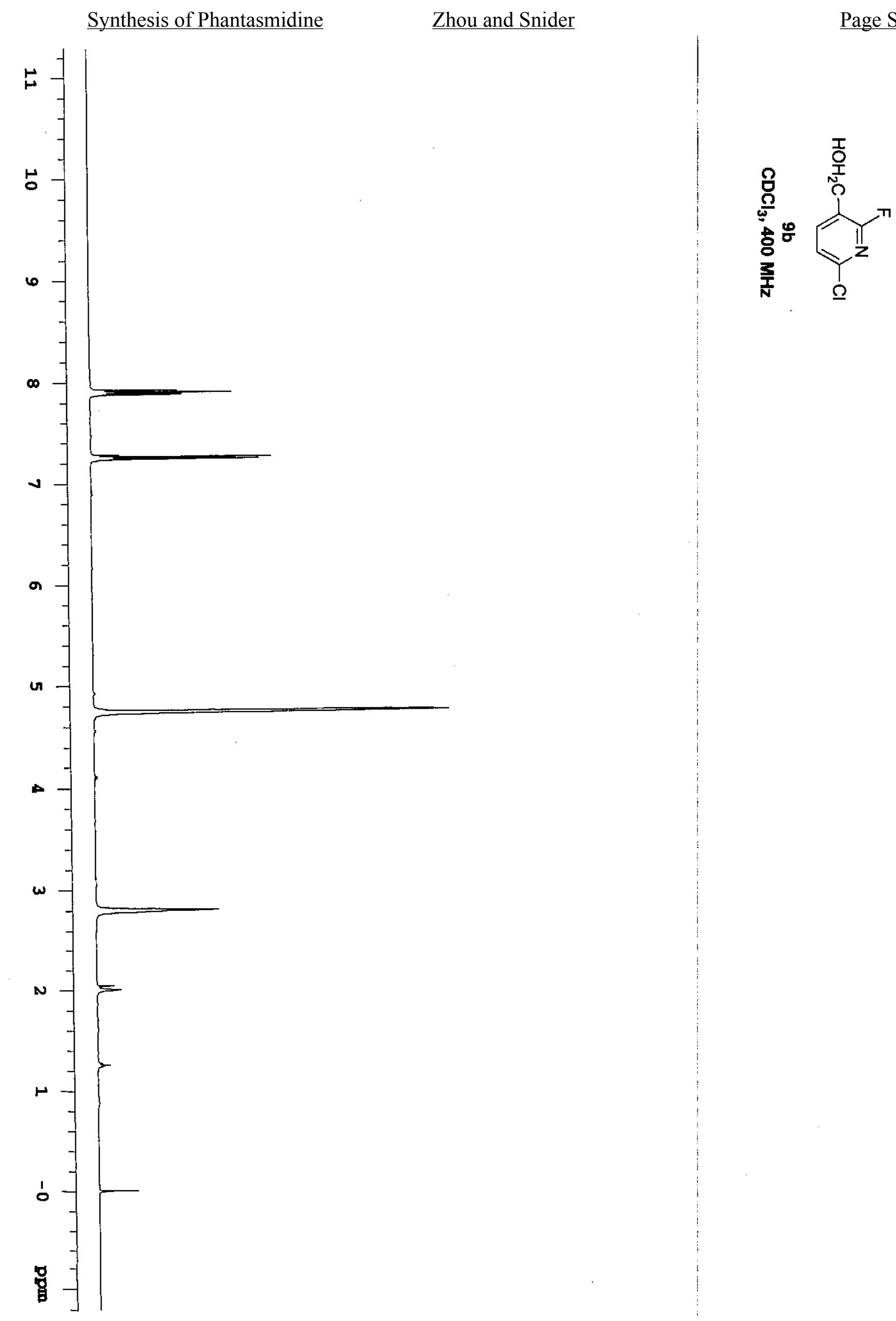
Synthesis of Phantasmidine

$\underline{\text { Zhou and Snider }}$

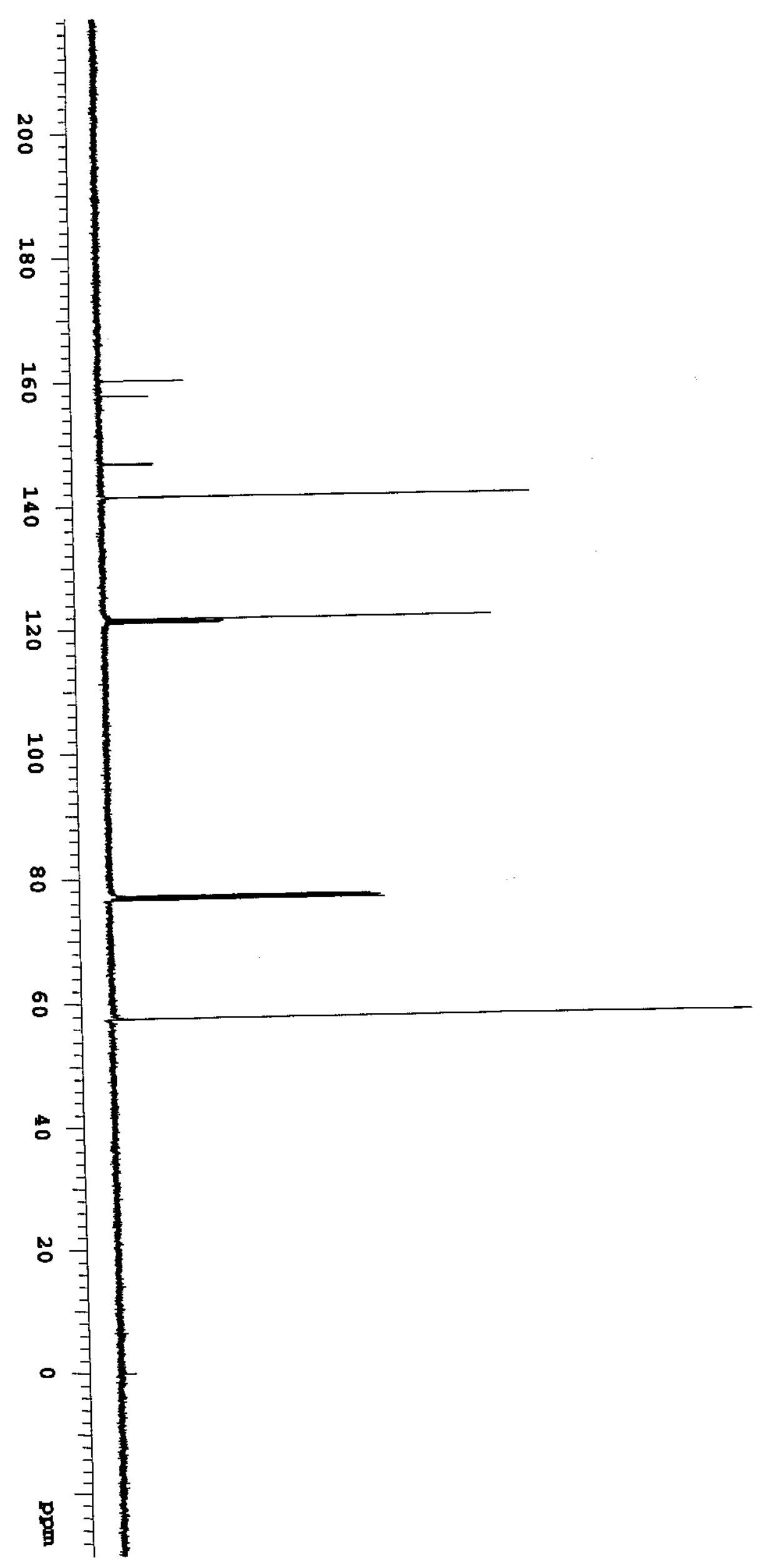

\section{Page S27}

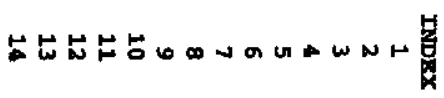

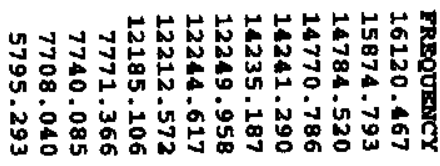

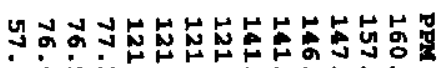

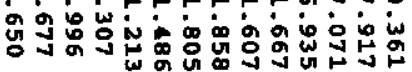

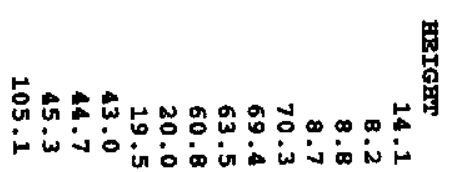

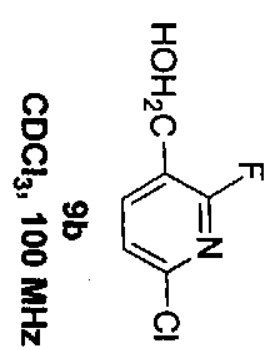


Synthesis of Phantasmidine

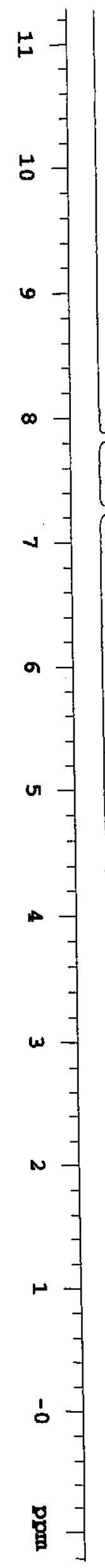

Zhou and Snider

$\underline{\text { Page S28 }}$

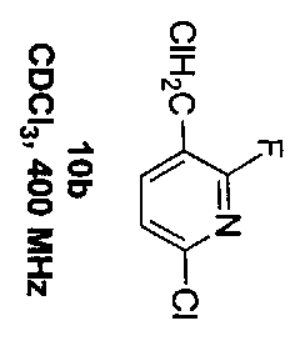




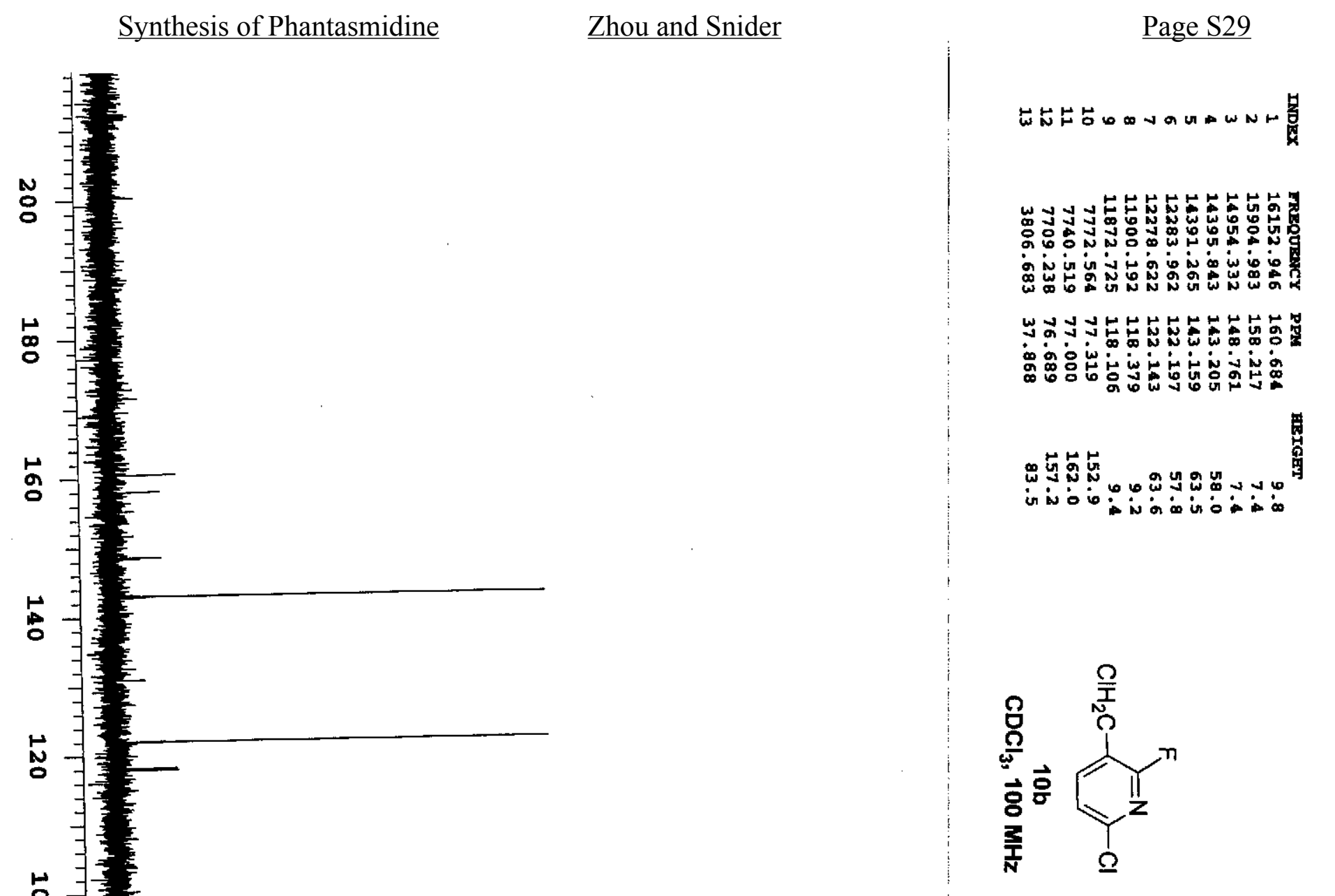



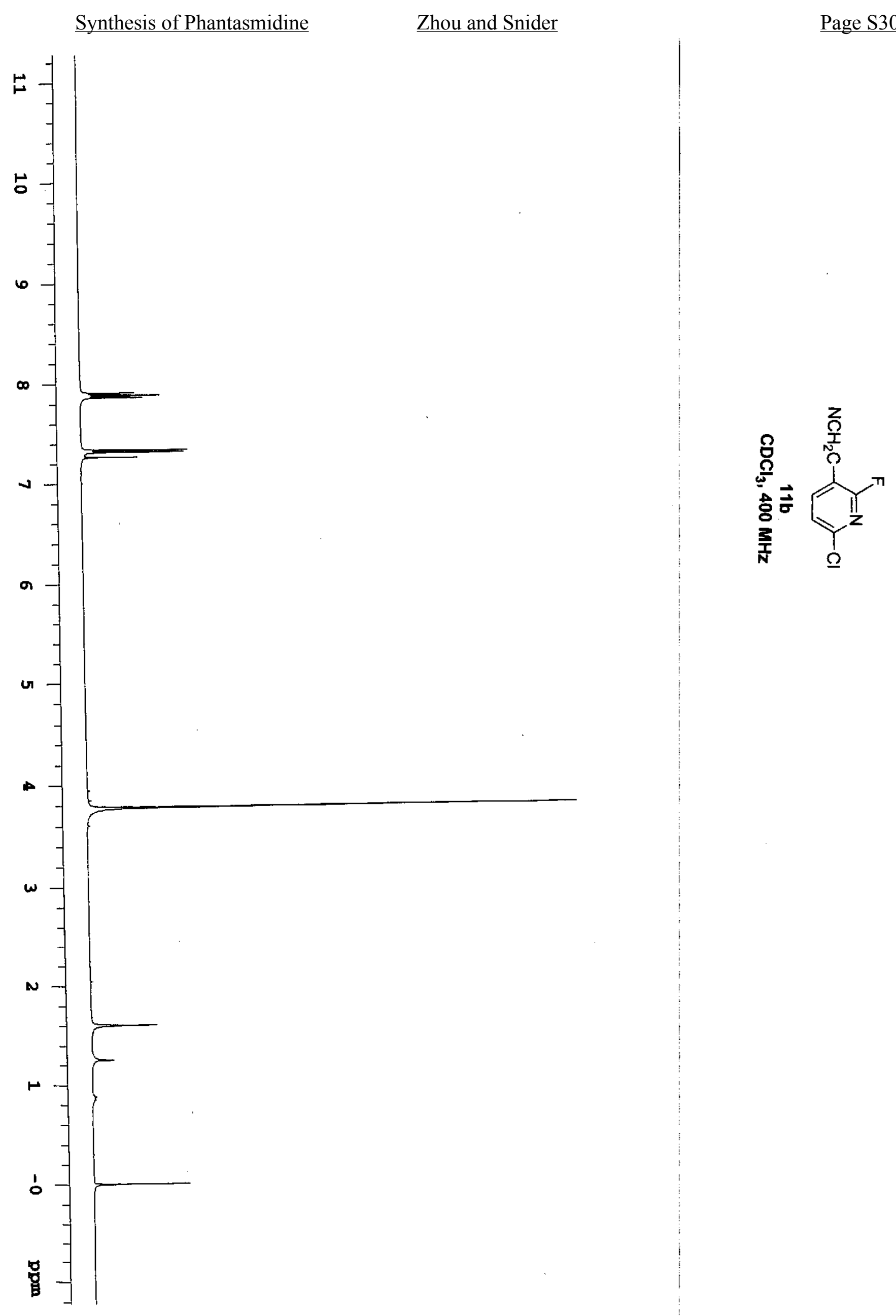
Synthesis of Phantasmidine

Zhou and Snider

Page S31

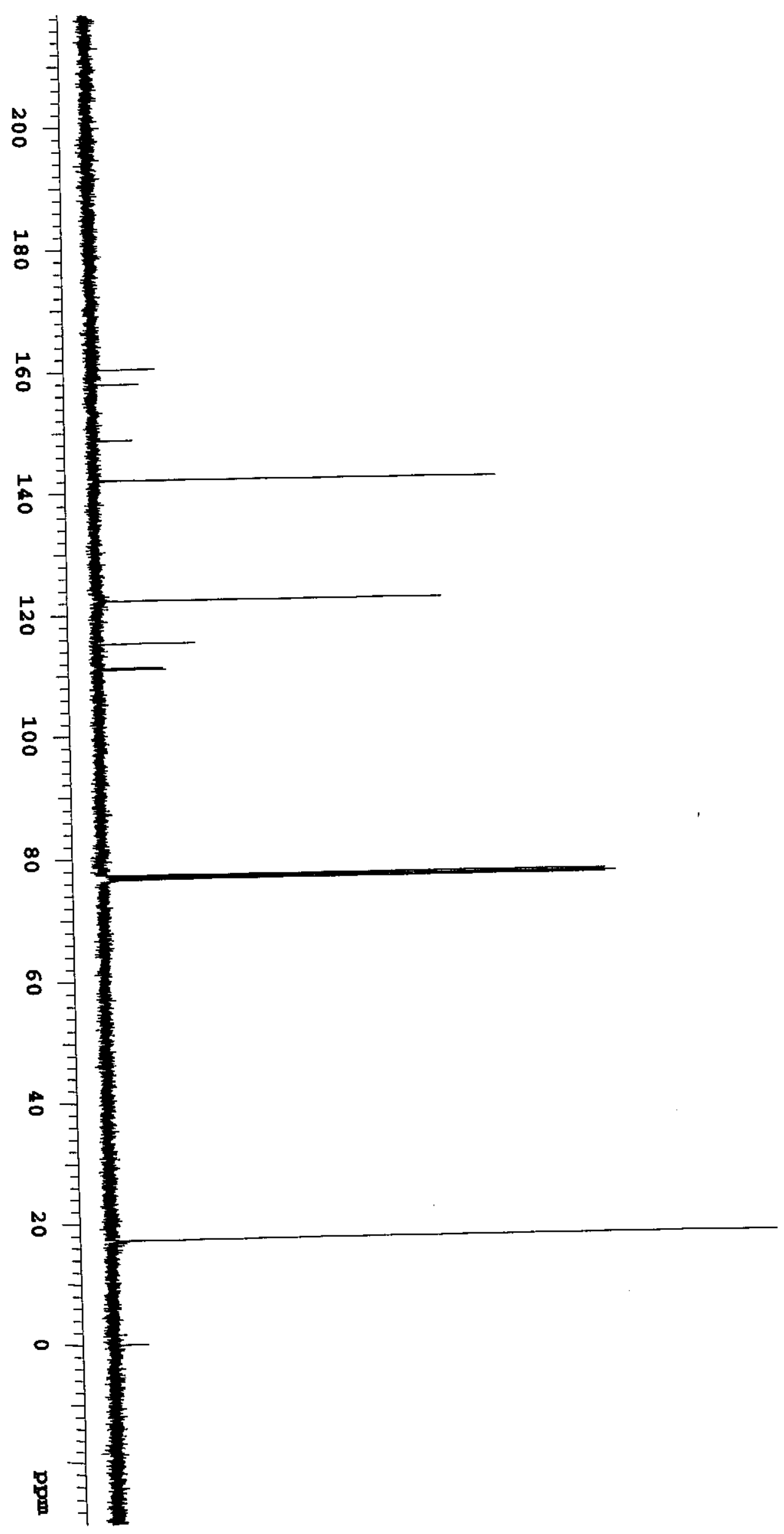

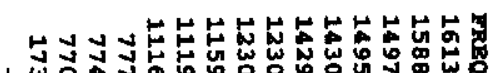

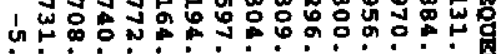

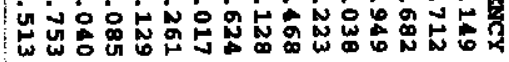

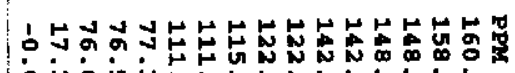

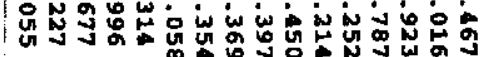

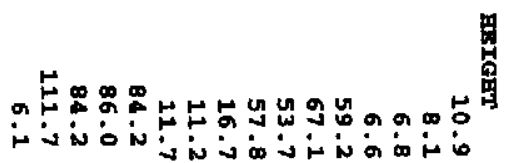<smiles>COc1ccc(O)cc1OCCO</smiles> 
Synthesis of Phantasmidine

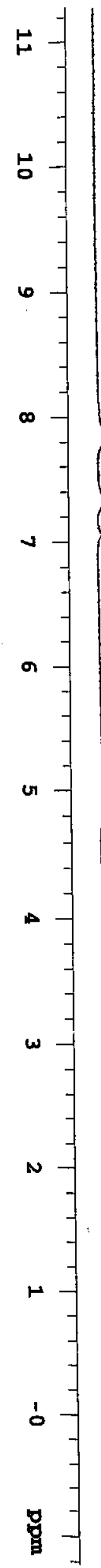

$\underline{\text { Chou and Snider }}$

Page S32

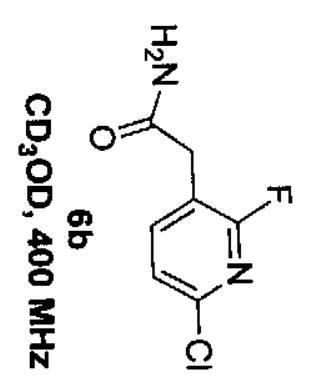




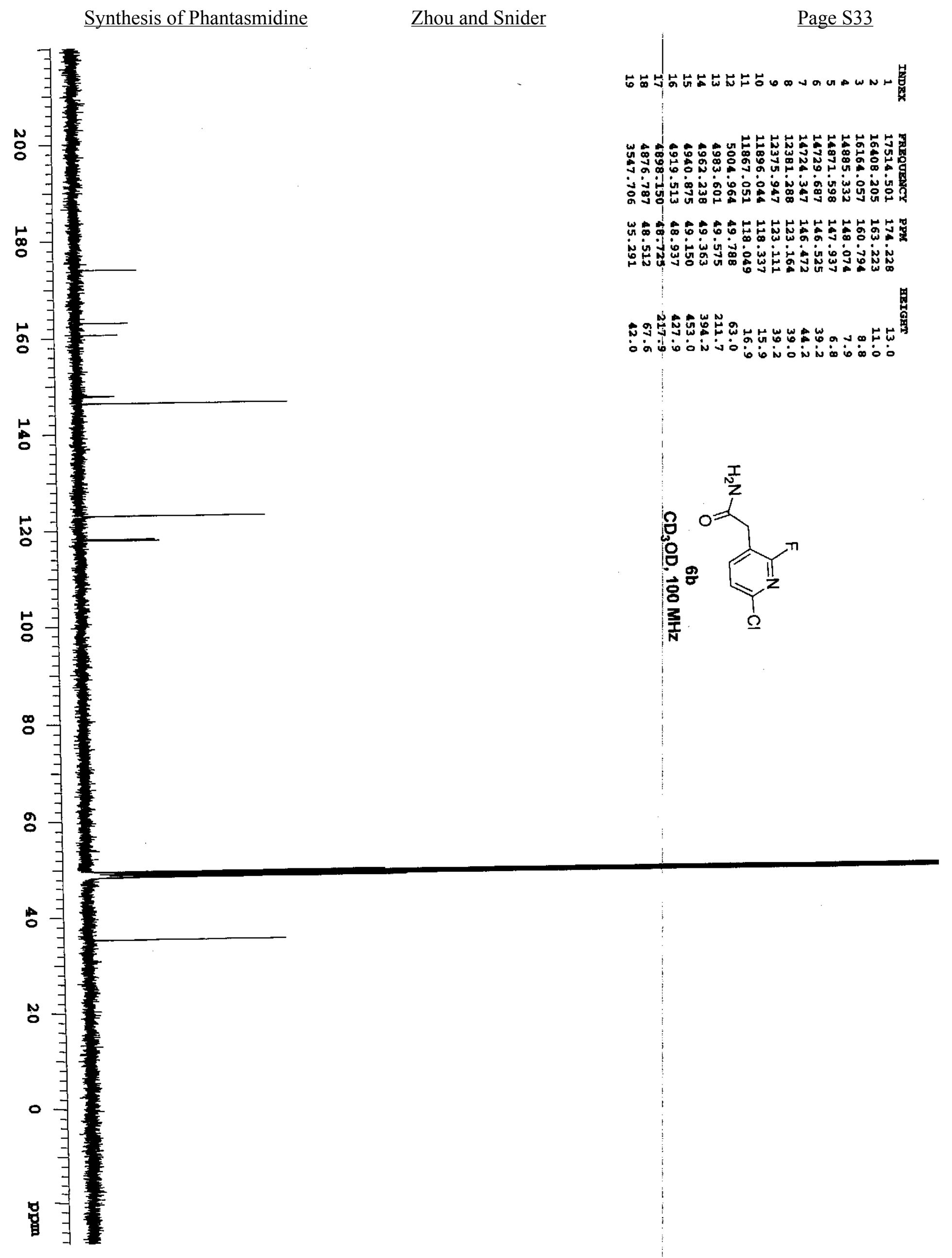


Synthesis of Phantasmidine

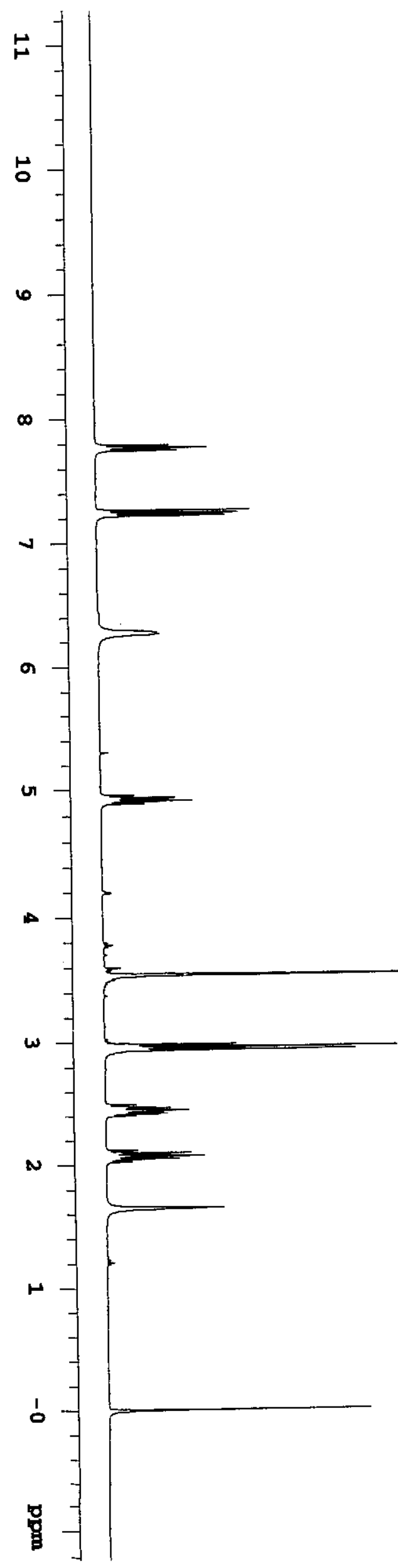

Zhou and Snider

Page S34 


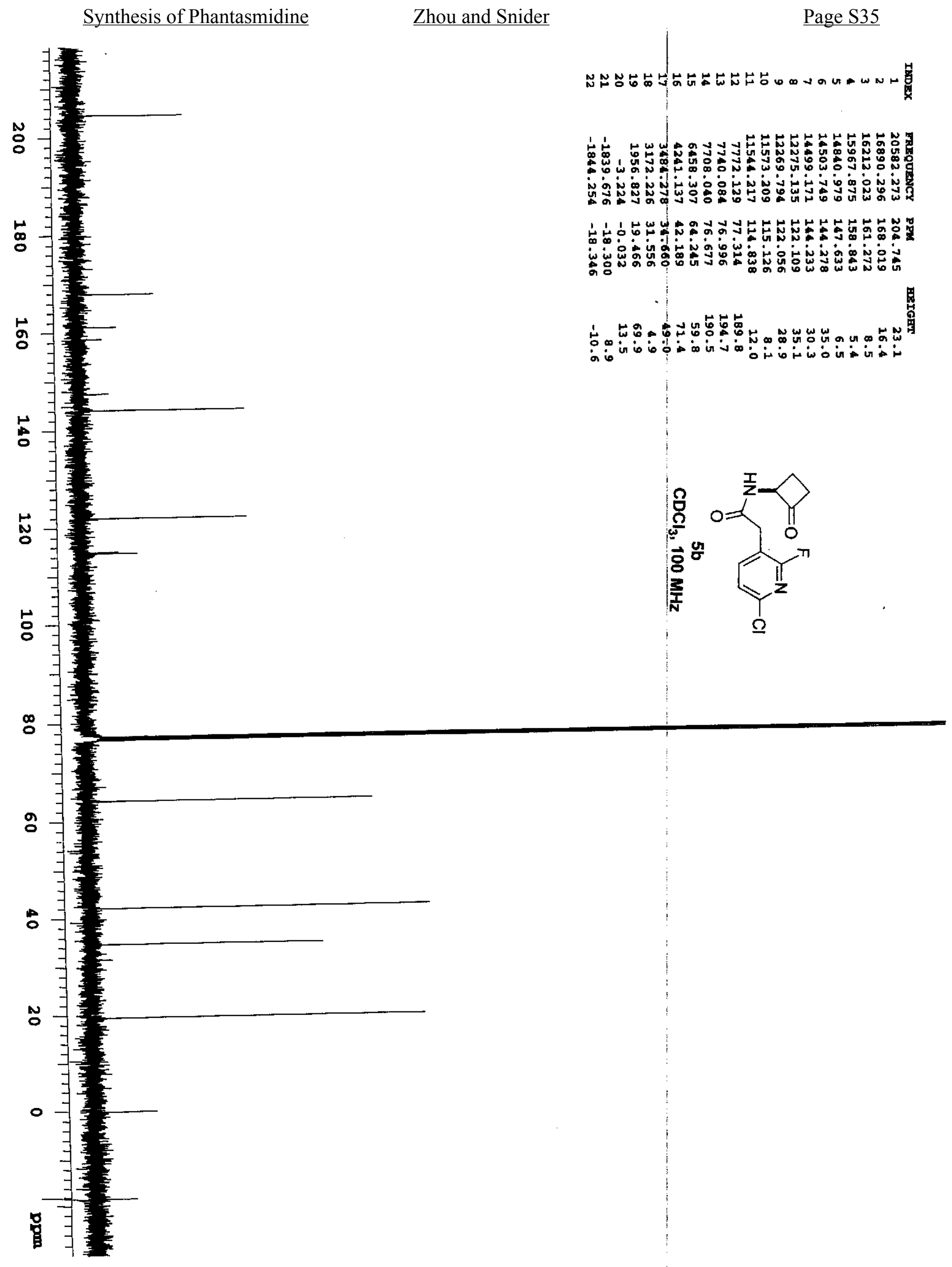


Synthesis of Phantasmidine

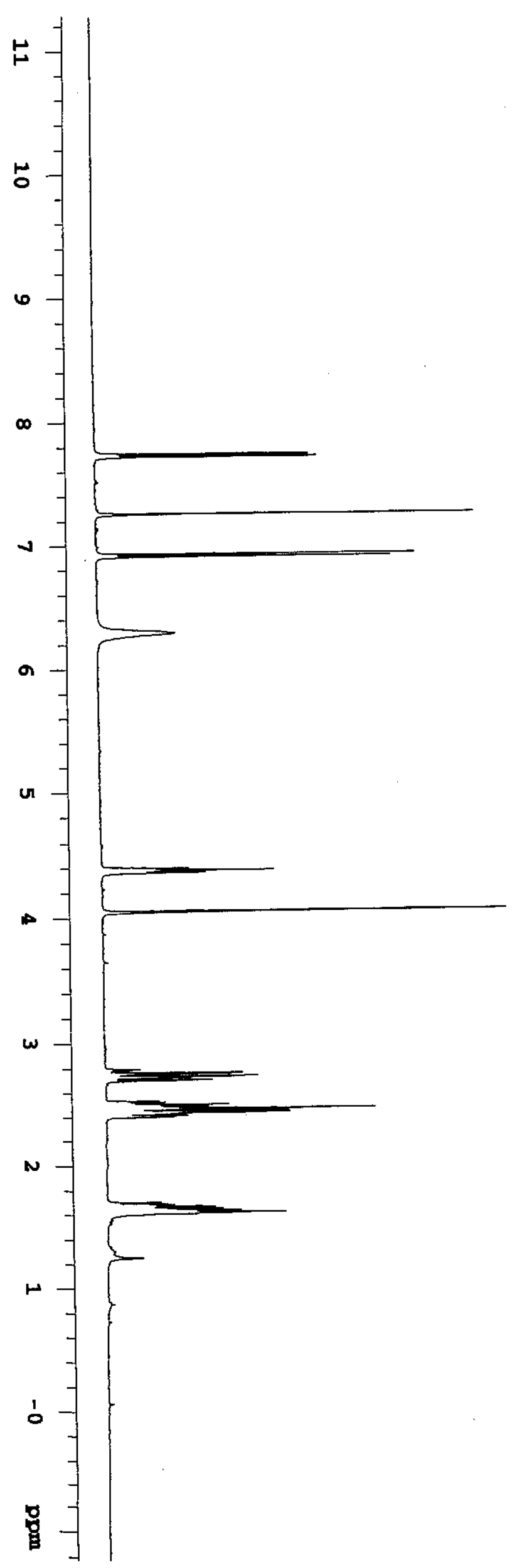

Chou and Snider

Page S36

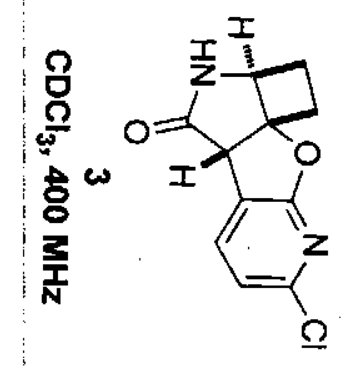




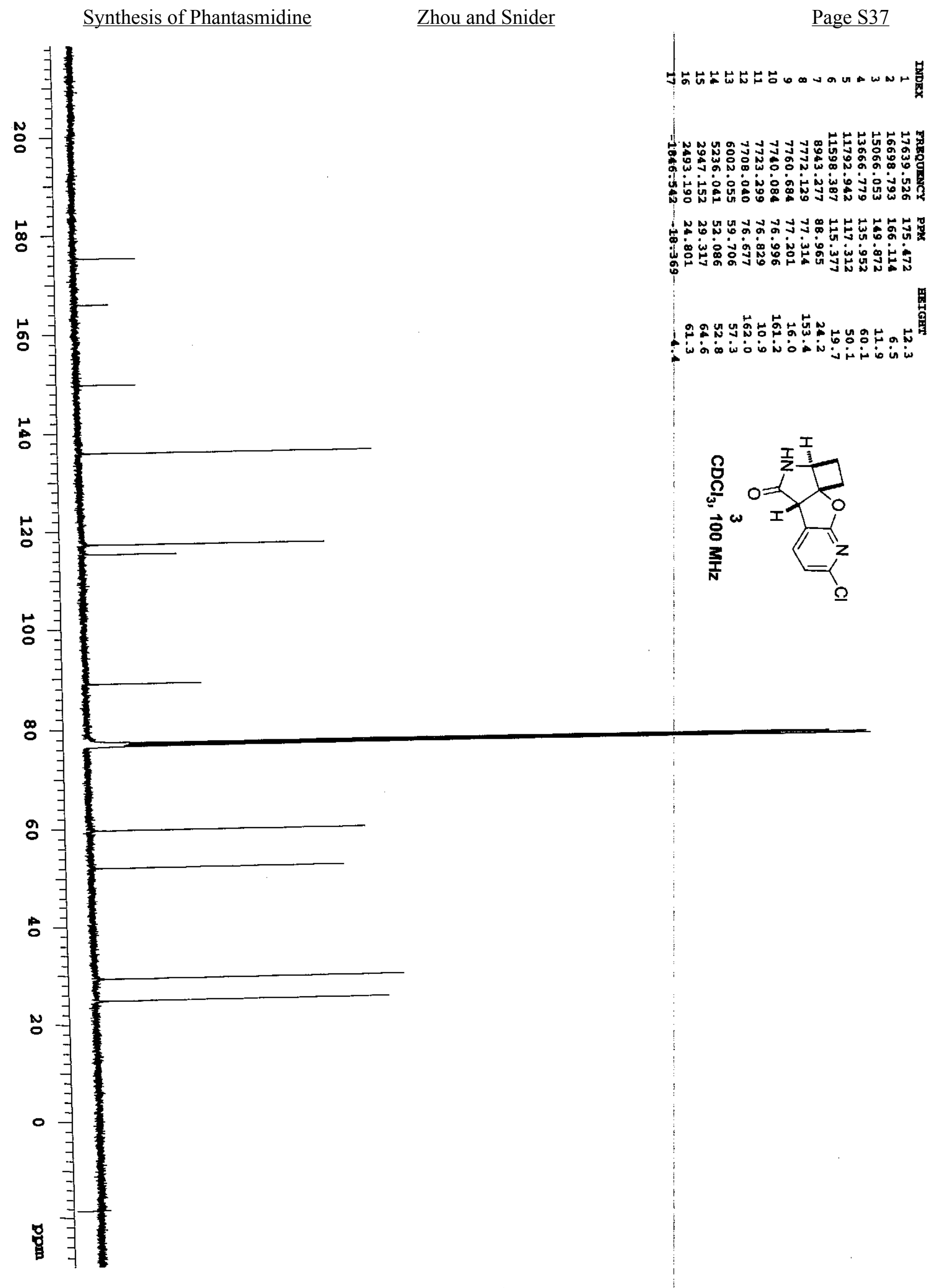


Synthesis of Phantasmidine

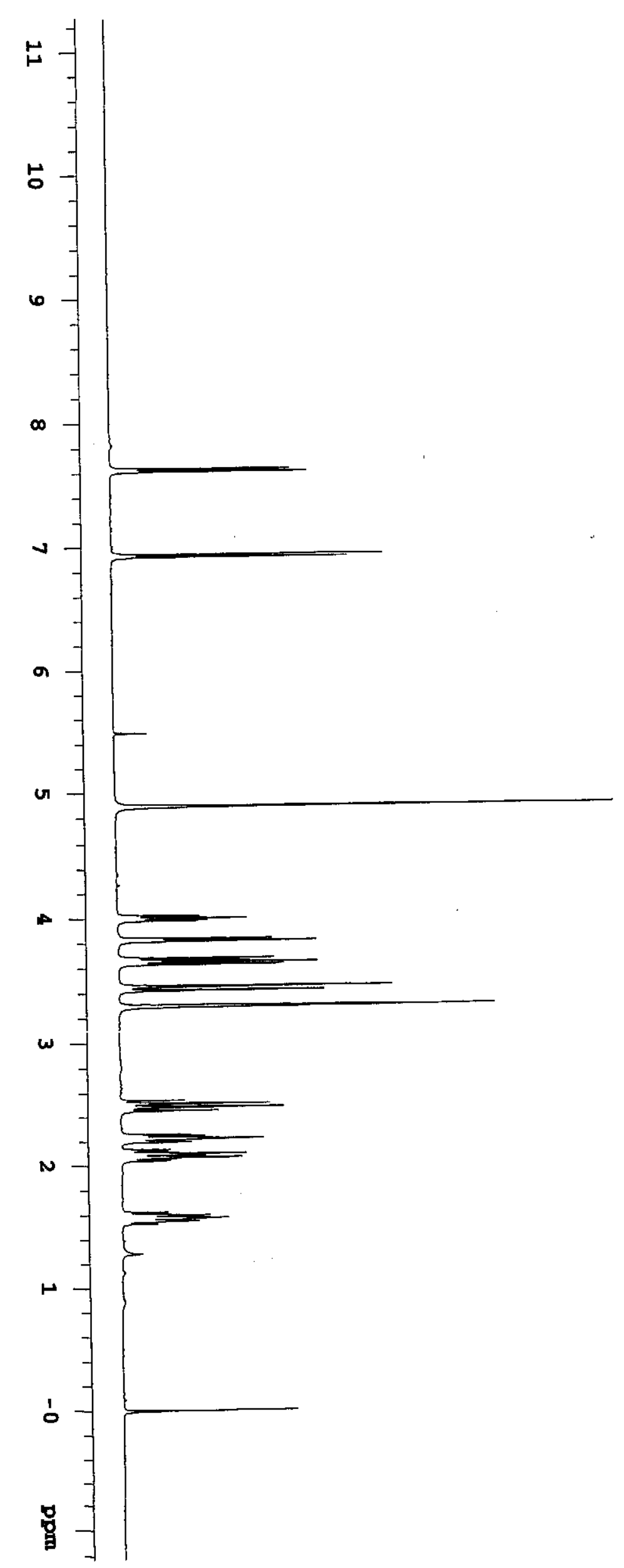

\section{Page S38}

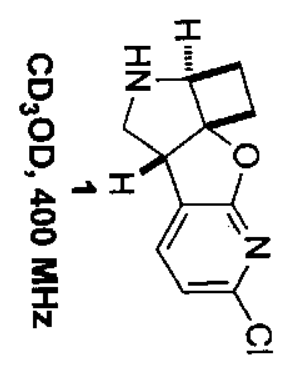




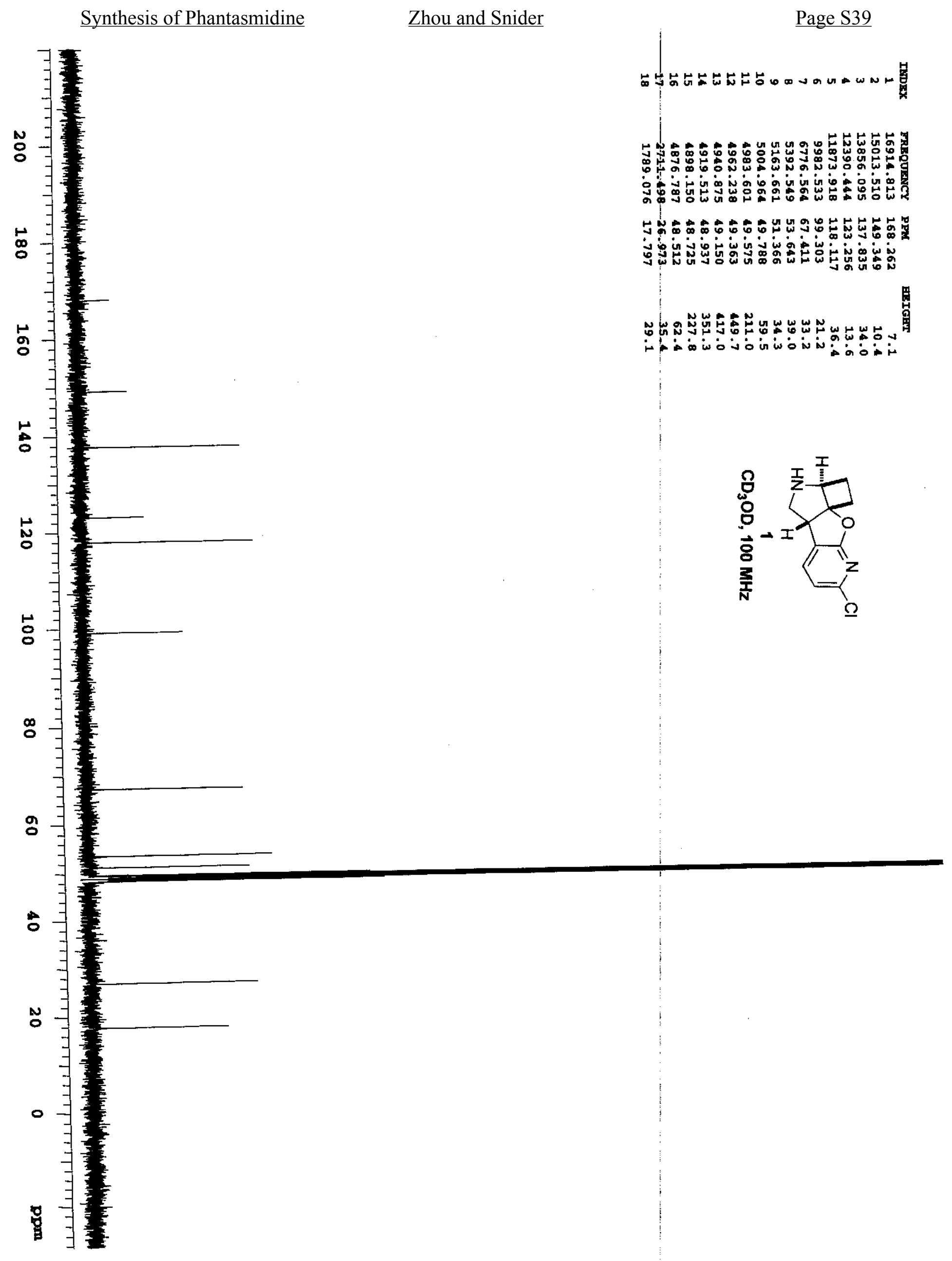




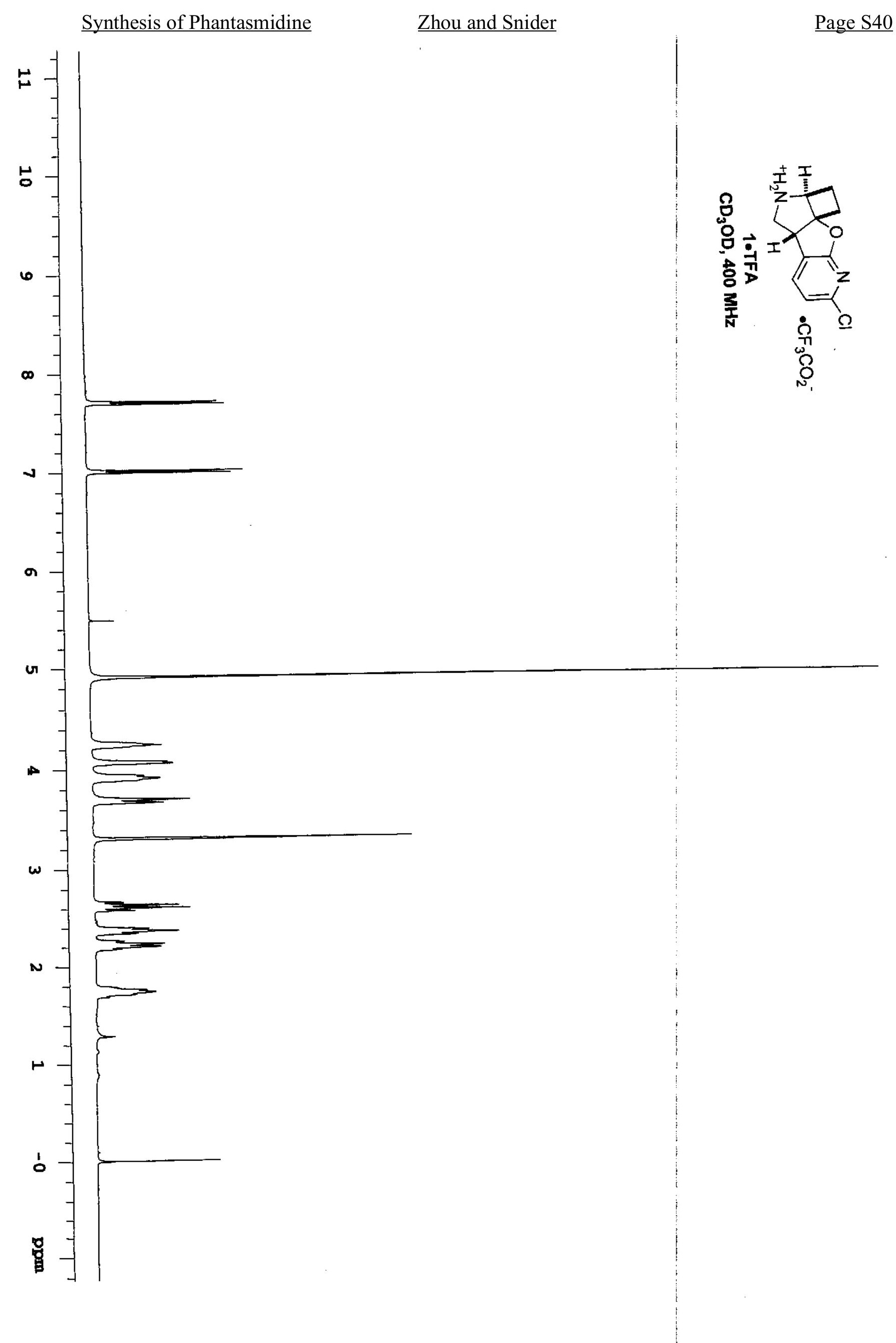


Synthesis of Phantasmidine

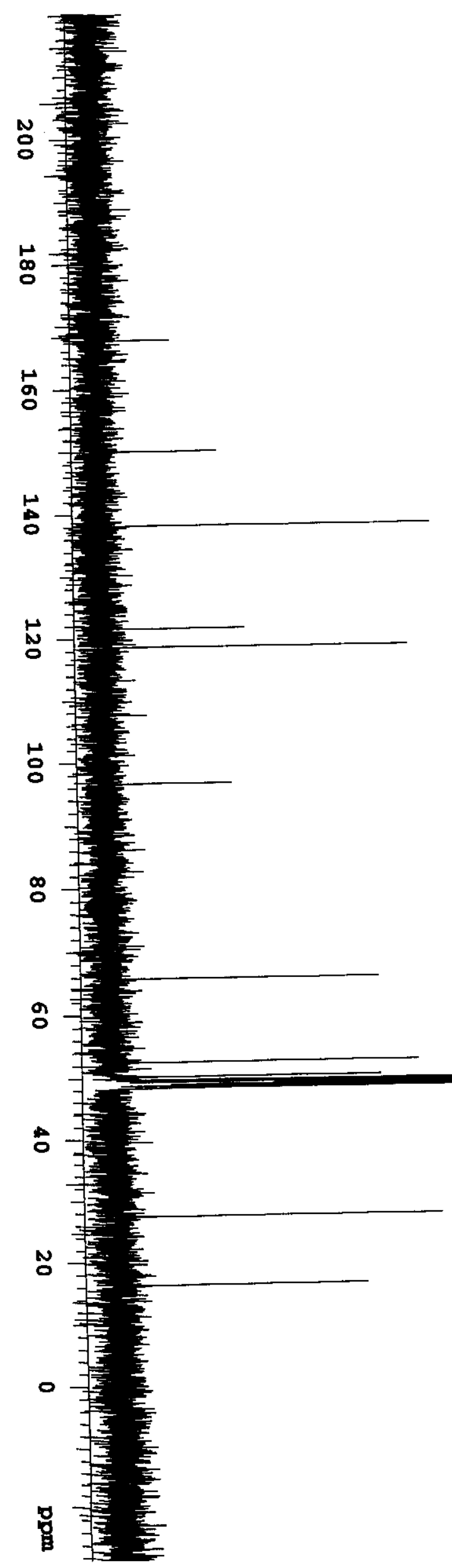

Zhou and Snider

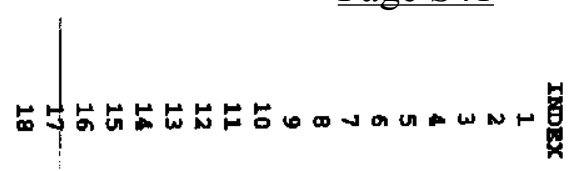

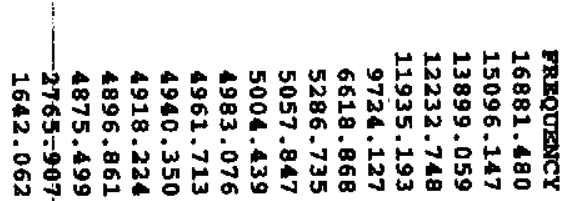

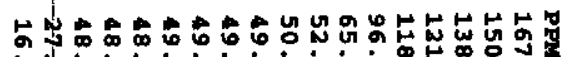

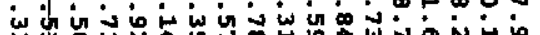

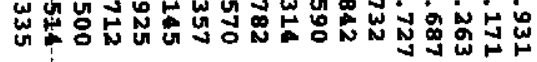

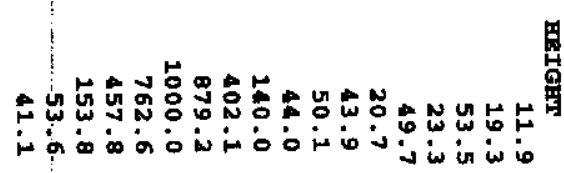


Synthesis of Phantasmidine

Zhou and Snider

Page S42

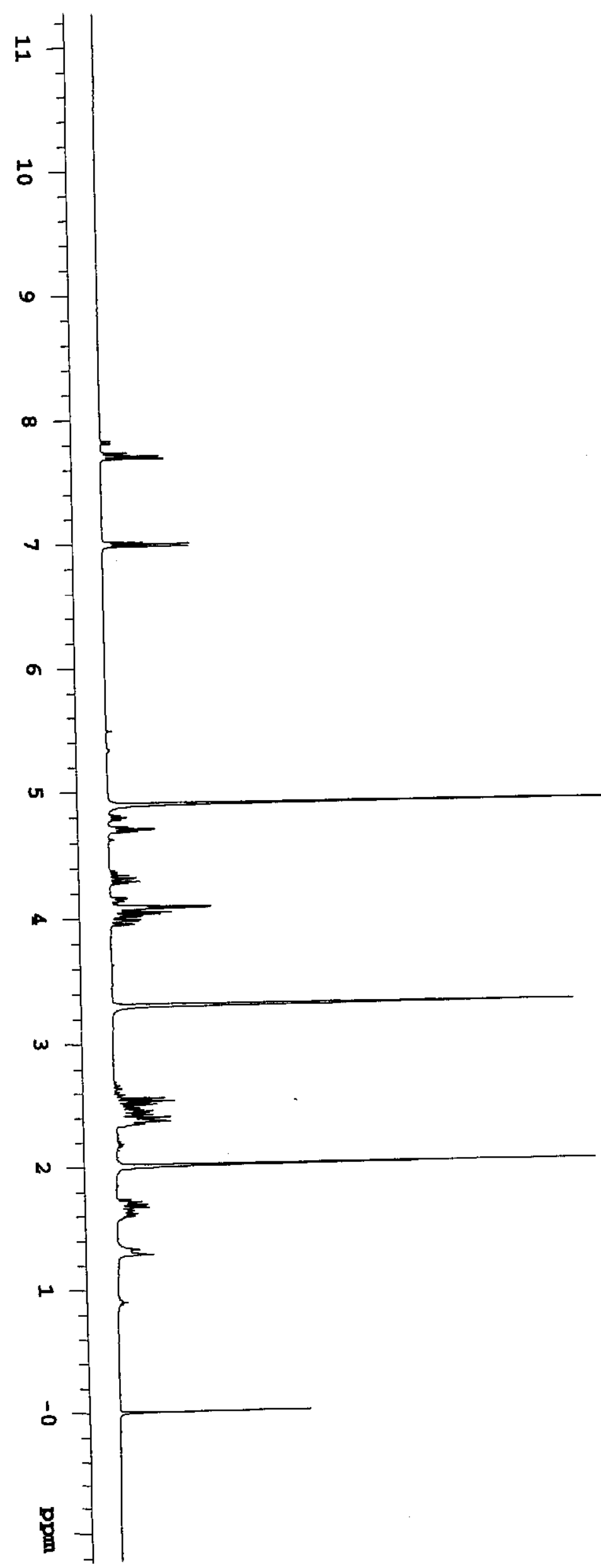




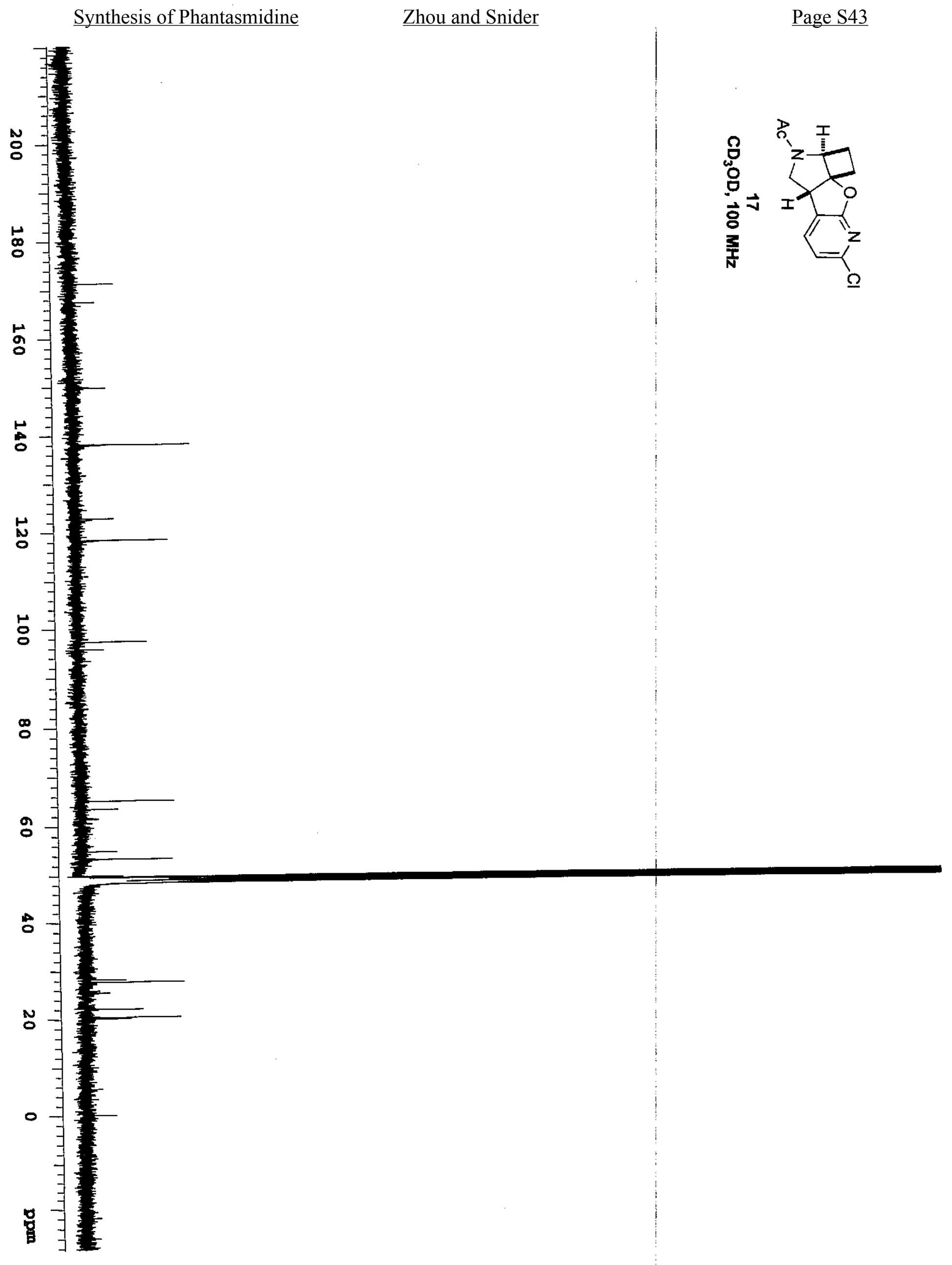




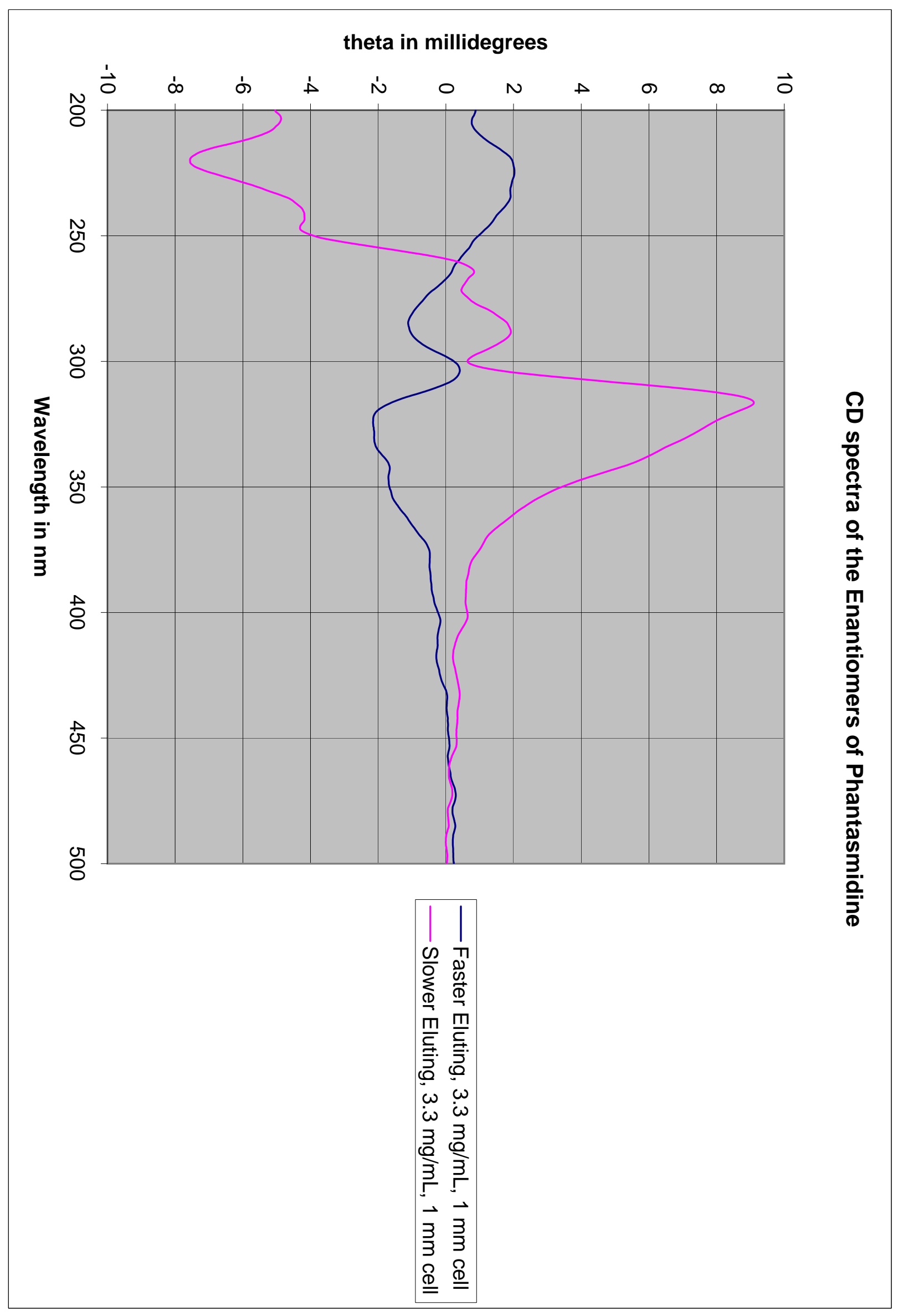

